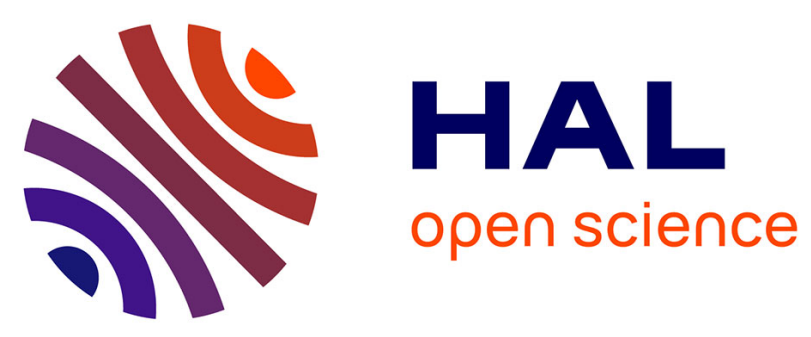

\title{
HyMeX-SOP1: The Field Campaign Dedicated to Heavy Precipitation and Flash Flooding in the Northwestern Mediterranean
}

Véronique Ducrocq, Isabelle Braud, Silvio Davolio, Rossella Ferretti, Cyrille Flamant, Agustin Jansa, Norbert Kalthoff, Evelyne Richard, Isabelle Taupier-Letage, Pierre-Alain Ayral, et al.

\section{To cite this version:}

Véronique Ducrocq, Isabelle Braud, Silvio Davolio, Rossella Ferretti, Cyrille Flamant, et al.. HyMeXSOP1: The Field Campaign Dedicated to Heavy Precipitation and Flash Flooding in the Northwestern Mediterranean. Bulletin of the American Meteorological Society, 2014, 95 (7), pp.1083-1100. 10.1175/BAMS-D-12-00244.1 . hal-00907518

\section{HAL Id: hal-00907518 https://hal.science/hal-00907518}

Submitted on 16 May 2020

HAL is a multi-disciplinary open access archive for the deposit and dissemination of scientific research documents, whether they are published or not. The documents may come from teaching and research institutions in France or abroad, or from public or private research centers.
L'archive ouverte pluridisciplinaire HAL, est destinée au dépôt et à la diffusion de documents scientifiques de niveau recherche, publiés ou non, émanant des établissements d'enseignement et de recherche français ou étrangers, des laboratoires publics ou privés. 


\section{HYMEX-SOPI}

\section{The Field Campaign Dedicated to Heavy Precipitation and Flash Flooding in the Northwestern Mediterranean}

by Véronique Ducroce, Isabelle Braud, Silvio Davolio, Rossella Ferretti, Cyrille Flamant, Agustin Jansa, Norbert Kalthoff, Evelyne Richard, Isabelle Taupier-Letage, Pierre-Alain Ayral, Sophie Belamari, Alexis Berne, Marco Borga, Brice Boudevillain, Olivier Bock, Jean-Luc Boichard, Marie-Noëlle Bouin, Olivier Bousquet, Christophe Bouvier, Jacopo Chiggiato, Domenico Cimini,

Ulrich Corsmeier, laurent Coppola, Philippe Cocquerez, Eric Defer, Julien Delanoë,

Paolo Di Girolamo, Alexis Doerenbecher, Philippe Drobinski, Yann Dufournet, Nadia Fourrié, jonathan J. Gourley, Laurent Labatut, Dominique Lambert, Jérôme Le Coz, Frank S. Marzano, Gilles Molinié, Andrea Montani, Guillaume Nord, Mathieu Nuret, Karim Ramage, William Rison,

Odile Roussot, Frédérique Said, Alfons Schwarzenboeck, Pierre Testor, Joël Van Baelen, Béatrice Vincendon, Montserrat Aran, and Jorge Tamayo

HyMeX-SOPI collected unprecedented observations of atmosphere, ocean, land, and rivers to improve the knowledge and prediction of the most damaging natural hazards in the Mediterranean.

$\mathrm{T}$ he distinctive topography and geographical location of the Mediterranean basin (Fig. 1) make the region prone to heavy precipitation and flash floods. Most of these events occur in autumn (September-November) over the western Mediterranean. The Mediterranean Sea acts as a vast heat and moisture source from which convective and baroclinic atmospheric systems derive their energy. The steep orography surrounding the Mediterranean Sea aids in lifting the low-level, conditionally unstable air, thus initiating condensation and convection processes. Daily surface rainfall greater than $100 \mathrm{~mm}$ is not uncommon for Mediterranean precipitation events. The coincidence of these heavy precipitation amounts superimposed on small and steep

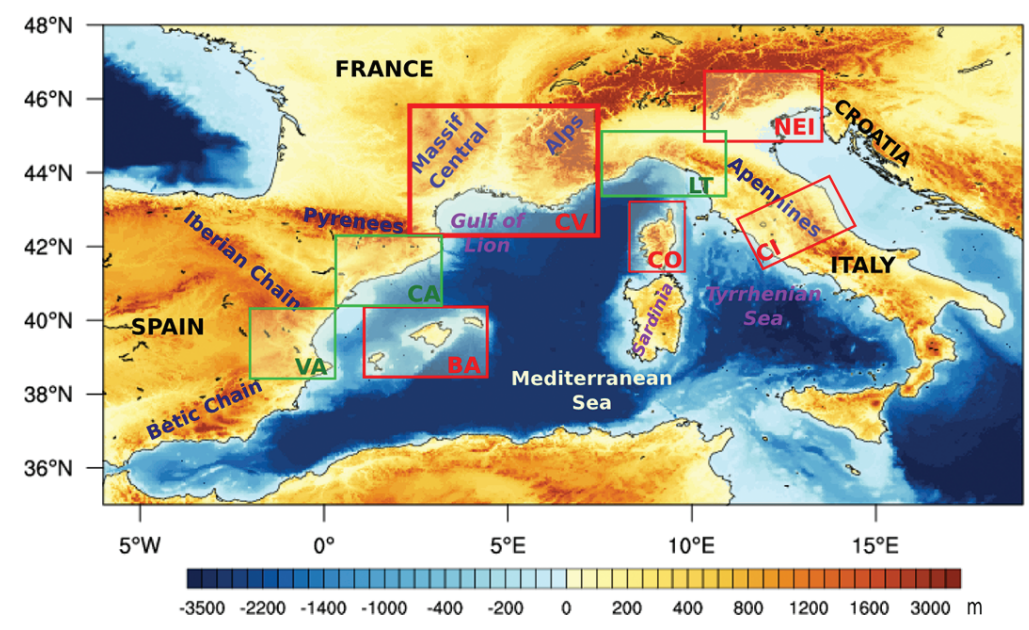

FIG. I. The western Mediterranean region together with the HyMeX sites: the Balearic Islands (BA), Catalonia (CA), and Valencia (VA) regions in Spain; Cévennes-Vivarais (CV) and Corsica (CO) in France; and central Italy $(\mathrm{Cl})$, Liguria-Tuscany (LT), and northeastern Italy (NEI) in Italy. Only sites delineated with red lines hosted research ground instruments. Note that the CV site includes not only the Cévennes-Vivarais mountain range (Massif Central) but also the French southern Alps. 
river catchments characteristic of the Mediterranean basin often induces devastating flash floods and flooding events. Each year, these events result in up to hundreds of millions of euros in damages and often casualties (e.g., Llasat et al. 2013; Munich RE 2011, 2012). Considerable efforts to improve the skill of the forecasts for such severe events have been made in recent years and significant progress has been realized through the development of convectionpermitting numerical weather prediction (NWP) systems. However, the accuracy of forecasts is still insufficient to satisfy the societal demands in terms of amount, timing, and basin-specific locations of rainfall and flash flooding. Our ability to predict such high-impact events remains limited because of the influence of finescale processes (e.g., convection, turbulence, microphysics) and their nonlinear interactions with larger-scale processes. Advances in the identification of the predominant mechanisms, and particularly of their interactions across scales, are mandatory in order to better forecast these events.

The Hydrological Cycle in the Mediterranean Experiment (HyMeX) offers a unique opportunity to improve our capabilities to predict these highimpact weather events. Major goals of the program include better quantification and understanding of

AfFiliations: Ducroce, Belamari, Bousquet, Doerenbecher, Fourrié, LABATUt, Nuret, Roussot, AND VINCENDON-CNRM-GAME, Météo-France/CNRS, Toulouse, France; BraUd AND LE CozIRSTEA, UR HHLY Unité de Recherche Hydrologie-Hydraulique, Lyon, France; DAVOLIO_-Institute of Atmospheric Sciences and Climate, CNR-ISAC, Bologna, Italy; FERRETTI-CETEMPS, Department of Physical Science and Chemistry, Università dell'Aquila, L’Aquila, Italy; FLAMANT AND DelanoË-LATMOS, UMR 8190 CNRS-UVSQ-UPMC, Guyancourt, France; JANSA AND TAMAYO-Agencia Estatal de Meteorología, Madrid, Spain; KALTHOFF AND CORSMEIER-Karlsruhe Institute of Technology, IMK-TRO, Karlsruhe, Germany; RICHARD, LAMBERT, AND SAID-Laboratoire d'Aérologie, Université de Toulouse/CNRS 5560, Toulouse, France; TAUPIER-LETAGE-MIO, AMU UMII0, CNRS UMR 7294, IRD UMR 235, USTV, Marseille, France; AYrAL-Ecole des Mines d'Ales and UMR 7300 ESPACE CNRS, Université de Nice-Sophia-Antipolis, France; BERNE-Environmental Remote Sensing Laboratory, École Polytechnique Fédérale de Lausanne, Switzerland; BORGADepartment of Land, Environment, Agriculture and Forestry, University of Padova, Italy; BOUdeVILLAIN, MolinIÉ, AND NORD-LTHE (UMR 5564 CNRS/IRD/Université de Grenoble), Grenoble, France; Bock-Laboratoire de Recherche en Géodésie (LAREG), IGN, Marne la Vallée, France; BoICHARD—Observatoire Midi-Pyrénées, Toulouse, France; BouIN-CNRM/CMM, Météo-France, Brest, France; BOUVIER-Hydrosciences Montpellier, Montpellier, France; CHIGGIATO-CNR-ISMAR, Venezia, Italy; CIMINI-CNR-IMAA, Tito Scalo, Potenza, Italy; CoppoLA—Observatoire Océanologique the water cycle in the Mediterranean with a strong emphasis on high-impact weather events (Drobinski et al. 2014). A key component of this program is its first field experiment, also called the special observation period (SOP1), dedicated to heavy precipitation and flash floods in northwestern Mediterranean. This article provides the rationale for developing this field experiment and general information on the design and operations of this field campaign. Three intensive observation periods (IOPs) are highlighted here to demonstrate the value of the SOP1 observation strategy for process understanding, model improvement, and data assimilation.

SCIENCE ISSUES. Heavy precipitation events (HPEs) in the Mediterranean are characterized by rainfall accumulations generally greater than $100 \mathrm{~mm}$ recorded in less than a day and often within just a few hours. These intense rainfall amounts typically come from quasi-stationary mesoscale convective systems (MCSs). For instance, MCSs were responsible for the rainfall that led to the dramatic flash-flood events in Vaison-la-Romaine in September $1992(300 \mathrm{~mm}$ in 4 h; Sénési et al. 1996), Liguria in October and November 2011 (450-500 mm in 6-12 h; Silvestro et al. 2012; Rebora et al. 2013), Gard in September

de Villefranche-sur-mer, France; CoCQUEREZ-Centre National d'Etudes Spatiales, Toulouse, France; Defer—LERMA, Observatoire de Paris, Paris, France; DI GIROLAMO-Scuola di Ingegneria, Università degli Studi della Basilicata, Potenza, Italy; DROBINSKILMD/IPSL, CNRS/Ecole Polytechnique, Palaiseau, France;

DUFOURNET-Delft University of Technology-Climate Institute, The Netherlands; GoURLEY-NOAA/National Severe Storms Laboratory, Norman, Oklahoma; MARZANO_DIET, Sapienza, University of Rome, Rome, and CETEMPS, Department of Physical Science and Chemistry, Università dell'Aquila, L'Aquila, Italy; MoNTANIARPA-SIMC, Bologna, Italy; RAMAGE_IPSL, Palaiseau, France; Rison-New Mexico Tech, Socorro, New Mexico; SchwarZenboeck AND VAN BAELEN—Laboratoire de Météorologie Physique (LaMP), UMR6016, UBP and CNRS, Clermont-Ferrand, France; TESTORLOCEAN/IPSL, Paris, France; ARAN-Servei Meteorològic de Catalunya (SMC), Spain

CORRESPONDING AUTHOR: Véronique Ducrocq, CNRMGAME, UMR3589, Météo-France/CNRS,42 Av. Coriolis, 31057 Toulouse CEDEX, France

E-mail: veronique.ducrocq@meteo.fr

The abstract for this article can be found in this issue, following the table of contents.

DOI:10.1175/BAMS-D-12-00244.I

A supplement to this article is available online (10.1175/BAMS-D-12-00244.2)

In final form 5 September 2013

(C)2014 American Meteorological Society 
2002 (about $700 \mathrm{~mm}$ in $24 \mathrm{~h}$; Delrieu et al. 2005), and Valencia in November 1987 (more than $800 \mathrm{~mm}$ in $24 \mathrm{~h}$; Romero et al. 2000). These storm systems are generally back-building quasi-stationary MCSs (Bluestein and Jain 1985), with a V-shaped anvil (or plume) identified in the infrared satellite images. Back-building results from renewed convective development at the vertex of the $\mathrm{V}$, which faces the low-level marine flow.

The synoptic-scale patterns associated with HPEs are characteristic of Rossby wave breaking at the eastern end of the North Atlantic storm track. An upper-level low northwest of the impacted area, possibly associated with a warm conveyor belt, helps to generate low-level marine flow directed northward toward the coastal mountainous regions (Nuissier et al. 2011). The orography and thermal contrasts of the Mediterranean basin can also induce thermal lows and lee cyclogenesis (the most frequent being the Genoa cyclogenesis), which account for these favorable low-level flow circulations (Campins et al. 2006). In the autumn, the Mediterranean Sea is still relatively warm with high evaporation rates (Mariotti et al. 2002). Duffourg and Ducrocq $(2011,2013)$ estimated that the evaporation from the Mediterranean Sea accounts for $40 \%$ to $60 \%$ of the water vapor feeding the convective systems. The remaining moisture originates from the Atlantic Ocean (Winschall et al. 2012) or from North Africa (Turato et al. 2004), possibly associated with extratropical transition of tropical cyclones. Additionally, anomalously warm sea surface temperatures (SSTs) increase air-sea surface heat fluxes, which in turn moisten and destabilize the marine atmospheric boundary layer. It is not only the magnitude of heating and moistening of the boundary layer but also the spatial distribution, which depends on mixed-layer oceanic circulations and prior atmospheric forcing, that impact the marine low-level flow and thus the intensity and displacement of HPEs (Lebeaupin et al. 2006; Lebeaupin-Brossier et al. 2013).

Repeated triggering or sustaining of convective cells over the same region is essential for accumulating high rainfall totals in a short time. In addition to a slowly evolving synoptic situation (Nuissier et al. 2008; Ferretti et al. 2000), it is necessary to have a lifting mechanism that focuses the onset of deep convection at the same place. Orographic lifting has been widely proposed as the causative mechanism (e.g., Rotunno and Ferretti 2001; Bousquet and Smull 2006). When the conditionally unstable, low-level marine flow impinges upon the foothills bordering the western Mediterranean Sea (Fig. 1), deep, moist convection can be triggered and renewed at the same location as long as the flux of low-level moisture remains intact. However, orographic precipitation associated with conditional convective instability is very sensitive to a number of factors related to cloud microphysical processes and to the complexity of the orography itself (Miglietta and Rotunno 2009, 2010). Furthermore, coastal mountains are not the only sources of lifting. Mountains and islands in the Mediterranean alter the low-level circulation over the sea (e.g., lee cyclones, channeling, and wake effects), frequently generating low-level convergence responsible for convective initiation (Buzzi and Foschini 2000; Jansa et al. 2001; Davolio et al. 2009). Frontal lifting associated with quasi-stationary frontal systems may also help the release of convective instability. In addition, the formation of a cold pool beneath the convective system can force the uplift of the incoming flow. The establishment of a cold pool can maintain intense convective systems far upstream from the mountain barrier. For instance, the unusual location of the HPE over the Gard plain in September 2002 was explained by the presence of a low-level cold pool induced by the convective system itself (Ducrocq et al. 2008). These lifting mechanisms were further studied by examining how characteristics of a conditionally unstable flow impinging upon the coastal complex terrain of the northwestern Mediterranean influence the location and intensity of quasi-stationary MCSs (Bresson et al. 2012). Idealized numerical simulations showed that MCSs remained over the mountain slopes of the Massif Central when the ambient flow is either rapid or moist but upstream of the barrier when the flow is relatively weak or dry (cold-pool triggering). Finally, neighboring mountain chains (i.e., the Alps and Pyrenees) have also been shown to impact convection through cold pool blocking within valleys and deflection of the low-level flow. It is worth pointing out that most of these results were obtained using convection-permitting model simulations and hence are dependent on the physical processes represented within the models.

HPEs occurring in coastal watersheds are responsible for the triggering of flash floods with a sudden and often violent onset and rapid rising time, typically from 1 to $6 \mathrm{~h}$ following the causative rainfall (Gaume et al. 2009). Their impacts are felt across scales as shown by the analysis of the 8-9 September 2002 Gard event in southern France where many casualties occurred in catchments less than $20 \mathrm{~km}^{2}$ that are typically ungauged (Ruin et al. 2008), whereas larger catchments (up to $1000 \mathrm{~km}^{2}$ ) suffered significant economic damages. Several factors and their combinations control flash-flood generation and 
impacts including the spatial and temporal variability of rainfall (Borga et al. 2008; Bouilloud et al. 2010), orography (Norbiato et al. 2009), geology and soils (Braud et al. 2010), initial soil moisture (Le Lay and Saulnier 2007; Tramblay et al. 2010), and geomorphological controls such as gorges and floodplains (Bonnifait et al. 2009). Identifying and quantifying the relative importance of these factors, however, remains challenging given the poor observations of flash floods.

A dedicated field campaign was thus designed to improve the present state of knowledge of Mediterranean HPEs and flash-flooding events and to improve numerical models. Among the previous field experiments, the most relevant one with respect to HyMeX SOP1 was the Mesoscale Alpine Program (MAP; Bougeault et al. 2001). It investigated orographic-induced precipitation in and around the Alps. One of its key findings was that accurate information on upstream conditions before the humid air reached the mountainous area can be as important as the model parameterizations for improving the quality of precipitation forecasts (Lascaux et al. 2004; Rotunno and Houze 2007). HyMeX SOP1 intends to fill this gap by sampling the upstream conditions. The SOP1 field campaign aimed at obtaining detailed information on the most extensive-to-date range of processes involved in the following four key components playing a role in heavy precipitation and flash flooding in the Mediterranean: 1) the mesoscale environment, and more specifically the upstream marine flows and their interaction with the complex terrain of the region; 2) air-sea exchanges and upperocean mixed layer prior to and during HPEs; 3 ) MCSs and associated cloud microphysical processes; and 4) hydrological response across scales leading to flash floods.

EXPERIMENTAL DESIGN. Observation sites and atmospheric ground networks. The domain of the field campaign was defined to encompass the regions most favorable to HPEs in the western Mediterranean and to be within the aircraft flight ranges (see Fig. 1). Within this large domain $(\sim 1400 \mathrm{~km} \times 700 \mathrm{~km})$, eight candidate sites all along the coastal mountainous regions were considered for experimental observations (Fig. 1). Among them, five subdomains were selected for deploying the research ground instruments, in addition to the operational meteorological and hydrological ground networks covering the larger SOP1 domain: the Cévennes-Vivarais (CV) and Corsica (CO) sites in southern France, the central Italy

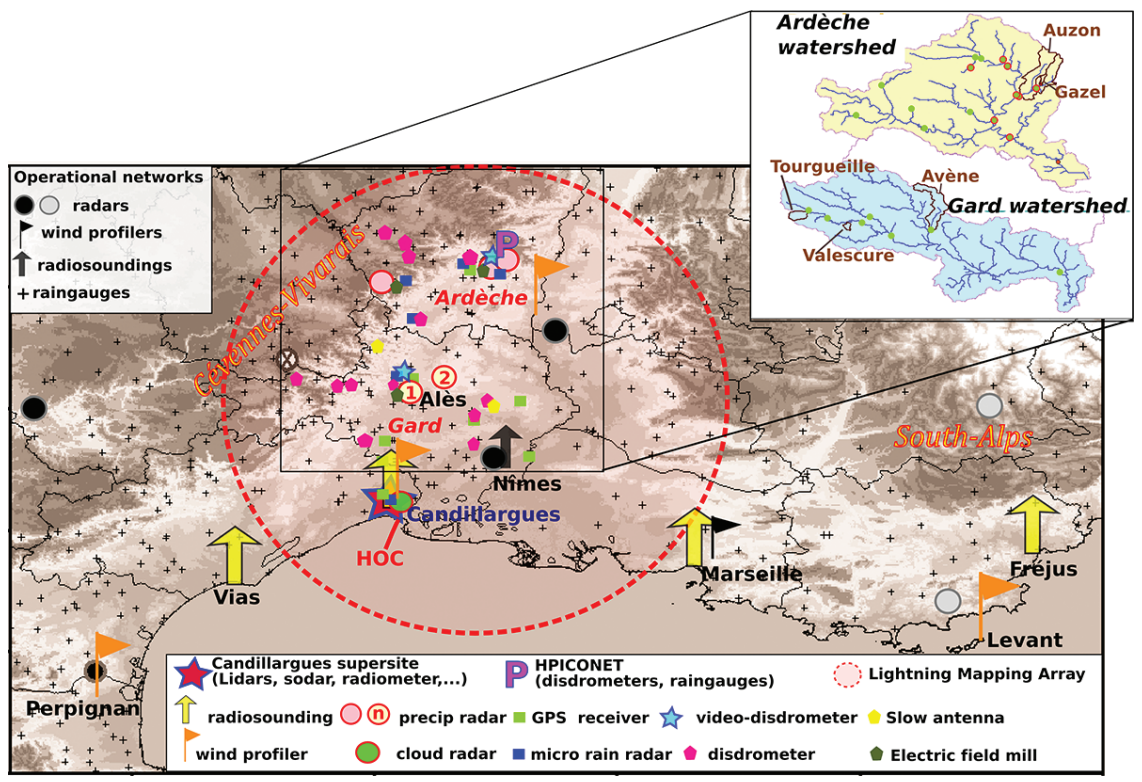

FIG. 2. Atmospheric ground instruments deployed over the CV site, together with the operational meteorological networks from Météo-France and other agencies (Services de Prévision des crues). The instrumented watersheds are shown in the upper panel, with gauging stations represented by green bullets and red-circled green bullets (gauging on demand). The HOC located at La Grande Motte is indicated. The radiosoundings at Marseille, Fréjus, and Vias are mobile stations. See Table ESI for a complete description of the other research instruments.
(CI) and northeastern Italy (NEI) sites, and the Spanish Balearic Islands (BA) site in Menorca. Supplemental Table ES1 (see the supplemental material online) provides a detailed description of the 165 research ground instruments that were deployed over the sites to sample the atmosphere.

Figure 2 shows the research instruments for the $\mathrm{CV}$ site, along with the operational networks that include five S-band and C-band Doppler radars (two of them being polarimetric) and rain gauges with a density of about one daily (hourly) rain gauge per 130 (180) $\mathrm{km}^{2}$. Instruments aimed at characterizing the nearupstream low-level flow include wind profilers and mobile radiosonde stations 

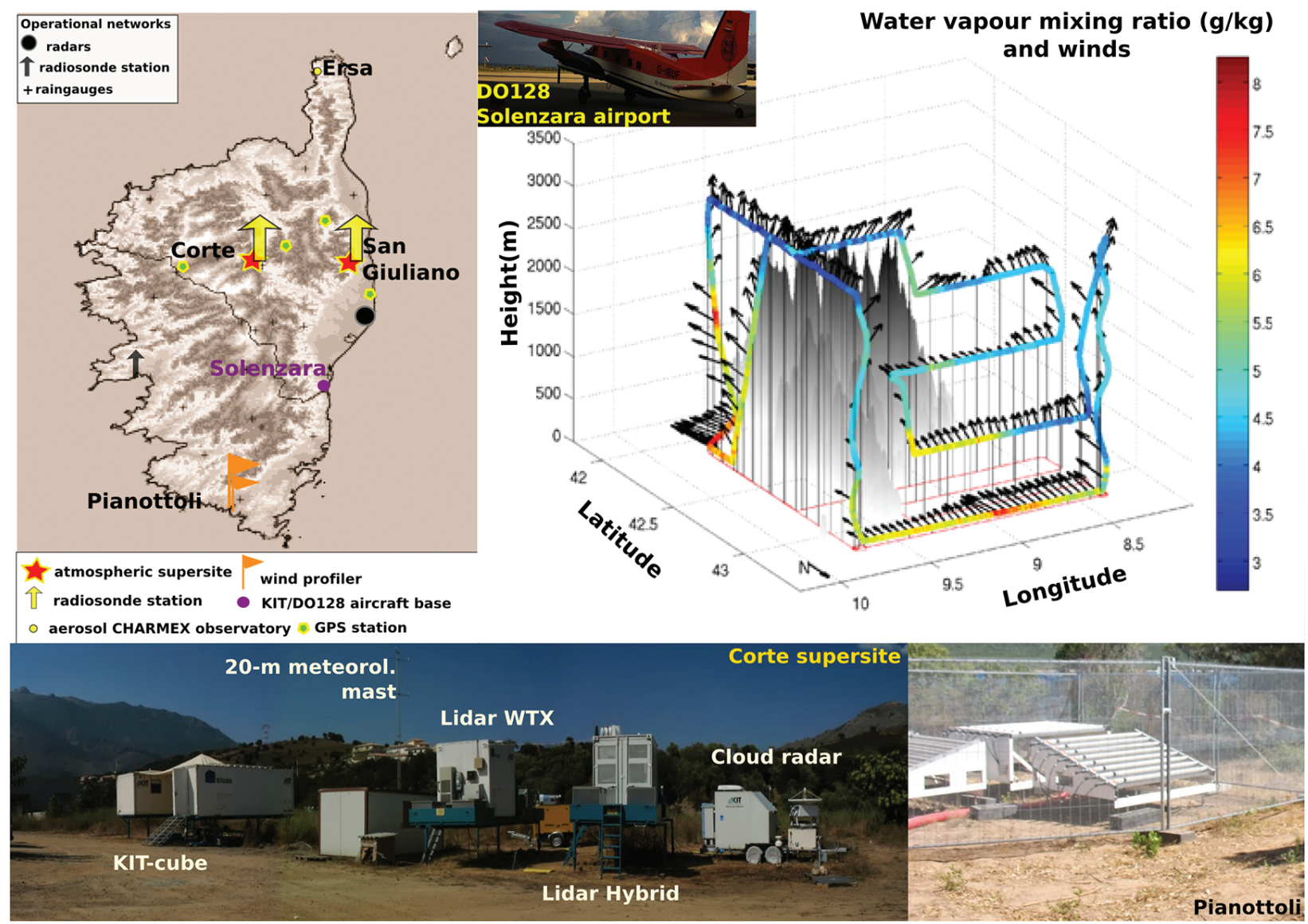

FIG. 3. Ground research instruments deployed over the $\mathrm{CO}$ site, together with the operational meteorological networks (upper left). Pictures of the instruments deployed at the Corte supersite and the wind profilers at Pianottoli are displayed in the bottom panels. The DO I28 research aircraft operated by University of Braunschweig and Karlsruhe Institute of Technology (KIT) together with time series of mixing ratio and winds during one flight are shown in the upper-right panel. See Table ESI for a complete description of the research instruments.

deployed along the coast, as well as a set of research instruments installed at the Candillargues atmospheric "supersite" near the coast and upstream of the Massif Central (CV mountain range). The microphysics, dynamics, and electric activity of the precipitating systems were observed within and upwind of the Cévennes-Vivarais mountain ranges using a Lightning Mapping Array (LMA), deployed for the first time in Europe, and radars, GPS receivers, and disdrometers distributed along two east-west transects and one north-south cross-coastal-barrier transect from the Candillargues supersite. The Hpiconet rain supersite, located in the eastern extremity of the northern east-west transect, aimed at characterizing the very finescale variability of the surface rainfall with one rain gauge or disdrometer per $4 \mathrm{~km}^{2}$.

The BA and CO island sites, often along the path of the marine flow, included a water vapor and aerosol lidar on Menorca (the northernmost Balearic island), which complemented the Palma de Majorca operational radiosoundings, and in the frame of the Centre d'Observation Régional pour la Surveillance du Climat et de l'environnement Atmosphérique et océanographique en Méditerranée occidentale (CORSiCA) atmospheric observatory (Lambert et al. 2011), two wind profilers in the south of Corsica, and two atmospheric supersites in Corte and San Giuliano (Fig. 3) equipped with near-surface and remote sensing instruments (Kalthoff et al. 2013). They were devoted to the characterization of the impact of the island on the marine flow and the description of the convection initiation and modification by the island, as well as to the monitoring of precipitating systems affecting the island. The CI and NEI sites deployed several radars, disdrometers, and MicroRain radars to describe the microphysics and kinematics of precipitating systems. The CI region included three atmospheric supersites (see detailed instrumentation 


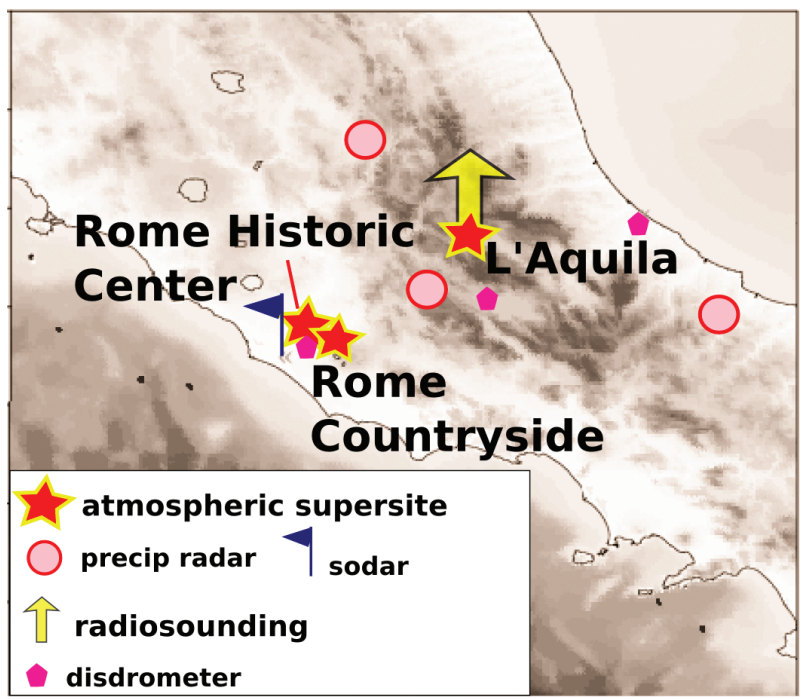

FIG. 4. Ground research instruments deployed over the $\mathrm{CI}$ site. See Table ESI for a complete description of the research instruments.

in Table ES1) distributed along a southwest-northeast transect in order to characterize the cross-coastalbarrier evolution of the precipitation from the Tyrrhenian Sea to the central Apennines (Fig. 4).

Aircraft and balloon operations. Three aircraft participated in the field campaign (Table 1). Supplemental Table ES2 provides the detailed payload for each aircraft and their flight trajectories. The French ATR42 and F20 operated by Service des Avions Français Instrumentés pour la Recherche en Environnement (SAFIRE) were based near the HyMeX Operation Center (HOC) at Montpellier airport, with possibility of refueling at the BA or $\mathrm{CO}$ site airports. The primary mission of the ATR42 was to characterize the inflow (structure, dynamics, thermodynamics, and aerosols) feeding heavy precipitating systems from their inception to mature phase. Its main payload consisted of the airborne differential absorption Lidar pour l'étude des intéractions Aérosols Nuages Dynamique Rayonnement et du cycle de l'Eau (LEANDRE 2) for profiling water vapor mixing ratio above or beneath the aircraft, depending on the cloud coverage, with vertical and horizontal resolutions of $150 \mathrm{~m}$ and $1 \mathrm{~km}$, respectively. The ATR42 payload also included in situ fast sensors for turbulence measurements as well as aerosol-cloud microphysics probes for characterizing the environment upstream of convective systems (water vapor, aerosol properties, planetary boundary layer dynamics/thermodynamics, and turbulence). The ATR42 performed mostly regional surveys over the Mediterranean Sea. Some ATR42 flights were also dedicated to turbulent flow measurements over the
Gulf of Lion and to lidar calibration/validation over the Candillargues supersite. The F20 aircraft aimed at characterizing the microphysics and kinematics within convective precipitating systems. It carried advanced microphysical in situ probes and a $95-\mathrm{GHz}$ Doppler cloud radar named Radar Aéroporté et Sol de Télédétection des propriétés nuAgeuses (RASTA) (Protat et al. 2009) for analyzing the interactions between physical/radiative properties of ice particles and the dynamics within the stratiform part of MCSs. The F20 released also dropsondes, mainly over the sea and within the vicinity of the precipitating systems. The German DO128 was based at the military airport in Solenzara (Fig. 3) and operated over and offshore of Corsica. The primary DO128 flight mission was to monitor the low-level conditions in the upstream region before and during HPEs. One other flight mission was to investigate the impact of the island of Corsica, in terms of orographic, thermal, diabatic, and aerodynamic influence, on the initiation and evolution of diurnal convection, MCSs, and on the embedded convection in cyclones. The DO128 was equipped with fast sensors to measure turbulent fluxes, water vapor inlet, and stable water isotope measurements (Corsmeier et al. 2001).

Boundary layer pressurized balloons (BLPBs) were launched from Menorca in order to sample the boundary layer over the northwestern Mediterranean Sea and, more specifically, the low-level inflow to precipitating systems (Table ES1). The balloons flew only over the sea at prescribed constant density levels corresponding to flight levels between 500 and $1000 \mathrm{~m}$ ASL. About 850 additional radiosoundings were launched during HyMeX SOP1 in order to refine the description of the mesoscale environment. Most of these radiosonde data were transmitted in real time to the Global Telecommunication System (GTS). As described in Table ES1, radiosoundings were launched from the $\mathrm{CO}$ site, from $\mathrm{CI}$, and from the mobile coastal stations and Candillargues supersite (CV site), where a new system for high-frequency boundary layer profiling recently proposed by Legain et al. (2013) was tested. Some radiosoundings were also launched from a ship (see below) to sample the near upstream inflow to precipitating systems. The other half of the radiosounding launches came from operational sites with a frequency increased upon special request to three or four balloons per day instead of two balloons per day. The requests for additional radiosoundings at operational radiosonde stations, namely at 0600 and 1800 UTC, were carried out under the EUMETNET composite observing system (EUCOS) framework and using the Data Targeting System (DTS) already 
implemented by the European Centre for MediumRange Weather Forecasts (ECMWF) (Prates et al. 2009) for the EURORISK-PREVIEW project and DTS-MEDEX-2009 experiment (Jansa et al. 2011). Two-thirds of the requested radiosoundings were made over Spain and southern France in order to monitor the upstream flow of the precipitating events. These regions often corresponded with the sensitive areas computed by the DTS.

Ocean measurements. The long-term ocean observations at the air-sea interface and of the upper ocean layer were enhanced during SOP1 over the western Mediterranean. Supplementary sensors were added to the two Météo-France anchored buoys located in the Gulf of Lion and along the French Riviera and 10 surface drifters (Marisonde, SVP-B) were dropped at sea (Table ES3). In addition, autonomous observation systems onboard a merchant vessel traveling weekly between Marseille and Algiers provided observations about the north-south cross-basin variability of the air-sea characteristics and of the column-integrated water vapor.

Regarding the upper ocean, and more specifically the mixed-layer heat content, several platforms were deployed during SOP1 to complement the observations of temperature and salinity performed by the 15 existing ARGO floats profiling the western Mediterranean. Several projects were leveraged (see Table ES3), resulting in the deployment of nine gliders (Testor et al. 2010) providing several 0-1000-m sections over the northwestern Mediterranean. The DOWEX2012 Mediterranean Ocean Observing System for the Environment (MOOSE) cruise from 5 to 20 September with the R/V Tethys II provided 54 profiles from a conductivity, temperature, and depth (CTD) water sampler. These observations provided a wide coverage of the heat and salt content over the northwestern Mediterranean basin and of its timespace variability. Last, a chartered vessel, the port tender P/T Provence, documented the near-upstream marine flow and the air-sea fluxes for three HPEs
(Table ES3). A total of 26 CTD ocean profiles down to $200 \mathrm{~m}$ were in addition performed from the $\mathrm{P} / \mathrm{T}$ Provence. Then, right after the end of SOP1, the R/V Urania carried out $\sim 60$ CTD ocean profiles in the Ligurian Sea and eastern Gulf of Lion.

Hydrological measurements. Over the CV site, a multiscale strategy for observing the hydrological responses to heavy precipitation was developed to cover 1) the hillslope scale, where process understanding on runoff generation and flow concentration can be addressed; 2) the small to medium catchment scale $\left(1-100 \mathrm{~km}^{2}\right)$, where the impact of stream network activation, rainfall, landscape, and initial soil moisture variability can be quantified; and 3) the larger scale $\left(100-1000 \mathrm{~km}^{2}\right)$, where hydraulic processes in rivers and flooding become important. We selected two larger-scale watersheds, the Gard and Ardèche River watersheds (Fig. 2), which have been extensively studied by the Cévennes-Vivarais Mediterranean Hydrometeorological Observatory (OHM-CV; Delrieu et al. 2005; www.ohmcv.fr) since 2002. Four subcatchments with typical Mediterranean landscapes (Valescure and Tourgueille in the Gard watershed and Claduègne and Gazel in the Ardèche watershed) were instrumented to monitor the soil moisture, surface runoff, and subsurface flow, as well as the flow discharges with distributed sensors (Table ES1). Several teams equipped with stream gauging equipment including surface velocity radars (SVRs) were tasked with gauging the discharges during events forecasted over the watersheds. Geochemical sampling of rainfall, rivers, and groundwater were also performed on demand for the Valescure catchment.

FIELD CAMPAIGN EXECUTION. Science and operations coordination. The SOP1 field campaign took place during nine weeks from 5 September to 6 November. This period captures the peak climatological period of HPEs in the northwestern Mediterranean. Besides the main science mission of

TABLE I. Aircraft information and science flight hours completed.

\begin{tabular}{|l|l|l|l|l|c|}
\hline Aircraft & Operator & $\begin{array}{c}\text { Flight altitude } \\
\text { range }\end{array}$ & Endurance & $\begin{array}{c}\text { Base of } \\
\text { operation }\end{array}$ & $\begin{array}{c}\text { Flight hours } \\
\text { completed }\end{array}$ \\
\hline Falcon20 & SAFIRE & $3-11 \mathrm{~km}$ & $\sim 3 \mathrm{~h} 30 \mathrm{~min}$ & Montpellier & 69 \\
\hline ATR42 & SAFIRE & $150 \mathrm{~m}-5 \mathrm{~km}$ & $\sim 3 \mathrm{~h} 30 \mathrm{~min}$ & Montpellier & 87 \\
\hline DOI28 & $\begin{array}{l}\text { IFG, TU Braunschweig, } \\
\text { Karlsruhe Institute of } \\
\text { Technology }\end{array}$ & Max height: $7 \mathrm{~km}$ & $\sim 3 \mathrm{~h} 30 \mathrm{~min}$ & Solenzara & 95 \\
\hline
\end{tabular}




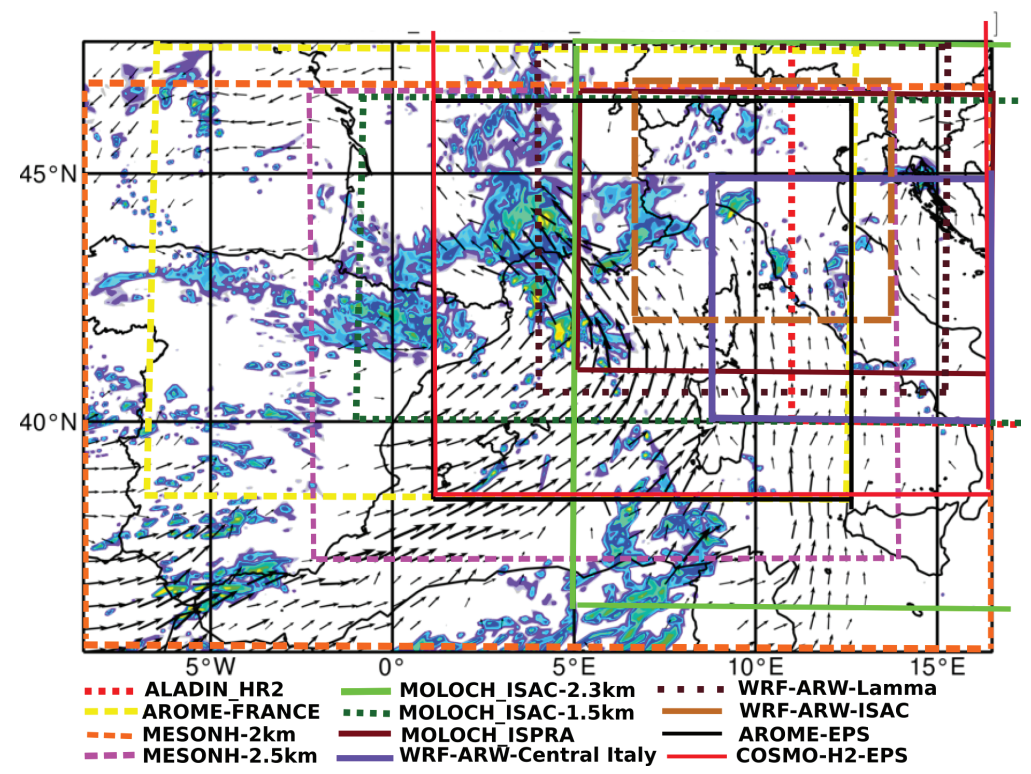

FIG. 5. The AROME-WMED domain with the intersections with all convection-permitting model domains. See Table ES4 for model characteristics. Background fields (reflectivity and winds at $850 \mathrm{hPa}$ for AROME_WMED forecast at 0800 UTC 26 October, IOPI6a) are an example of forecast outputs extensively used to define F20 flight plans.
NWP forecasts from the ECMWF Integrated Forecast System (IFS), Météo-France Action de Recherche Petite Echelle Grande Echelle (ARPEGE), Application of Research to Operations at Mesoscale (AROME), and AROME-WMED (for the western Mediterranean). This latter model was similar to the AROME operational convectionpermitting NWP suite over France (Seity et al. 2011), but with a larger domain extending southward to cover all the western Mediterranean (Fig. 5) and with a longer forecast range (up to $48 \mathrm{~h}$ ) for the flightplanning needs. In addition to the operational observations used in the 3-h data assimilation cycle, it assimilates some of the observations made available in real time for SOP1 (surface observations over Spain, radiosoundings from the research sites). Several other research convec-
SOP1 which was to document HPEs possibly associated with flash-flood events (FFE), we defined three other science missions of interest for HyMeX since they could benefit from the instrumented platforms: orographic (stratiform) precipitation (ORP), strong wind events (SWE), and lidar validation (LV) during clear nights over the Candillargues supersite.

The HyMeX Operation Center was located at La Grande Motte (Fig. 2), near the French aircraft base and the Candillargues supersite. Daily briefings were organized each morning in videoconference with secondary operations centers located in L'Aquila (Italy), Palma de Mallorca (Spain), San Guiliano (France), Menorca (Spain), and Toulouse (France). Considering the important and challenging role of weather forecasting in the operations planning, 10 Météo-France forecasters took turns seven days a week at the HOC, while the secondary operational centers provided valuable inputs concerning weather forecasts specific to their regions. Several Météo-France forecaster SYNERGIE workstations were deployed at the HOC to provide access to the real-time meteorological observations and tion-permitting models initialized with larger-scale model analyses were also run in real time in support of field operations, as well as two prototypes of future convection-permitting ensemble prediction systems (EPS) based on AROME and The Consortium for Small-scale Modeling (COSMO), respectively (Fig. 5). Altogether, forecast outputs from approximately 30 atmospheric research and operational models, as well as from three hydrological models and three ocean models driven by atmospheric numerical forecasts

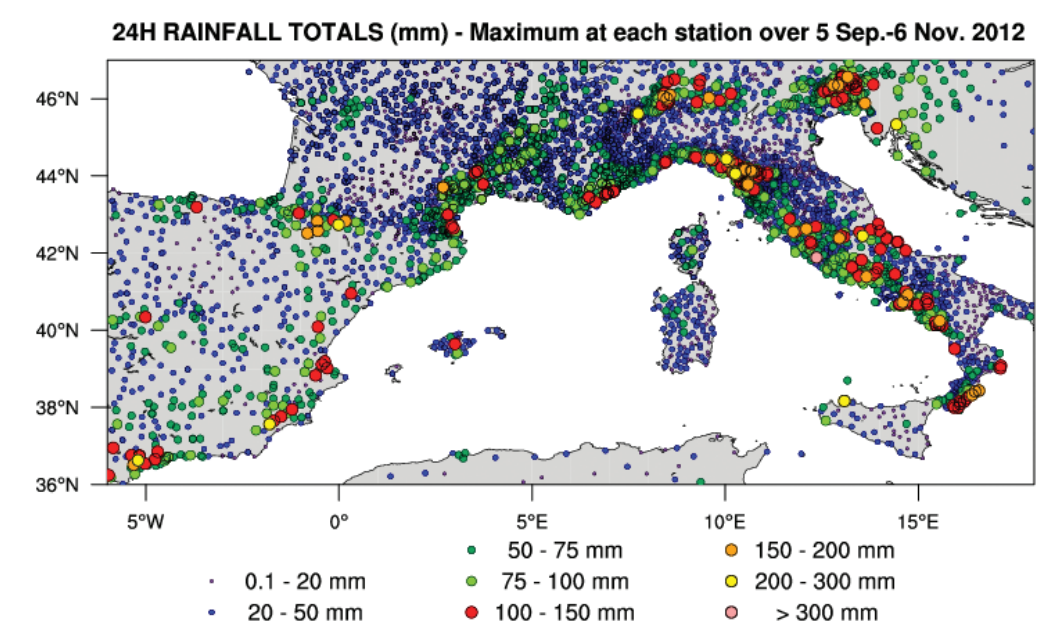

Fig. 6. Maximum 24-h rainfall totals at each station from 5 Sep to 6 Nov 2012, based on rain gauge observations received in near-real time during SOPI. 
(Table ES4), were made available in real time on the HyMeX SOP website (http://sop.hymex.org). About 300 scientists from France, Italy, Spain, Germany, the United States, the Netherlands, Austria, Switzerland, and Croatia were involved in the field operations and were able to check daily weather reports and IOP decisions on the HyMeX website.

Intensive observation periods. Figure 6 shows the maximum daily precipitation recorded at each rain gauge during the two-month field campaign. There were 20 days with daily rainfall accumulations exceeding $100 \mathrm{~mm}$ somewhere in the SOP domain. Monthly precipitation

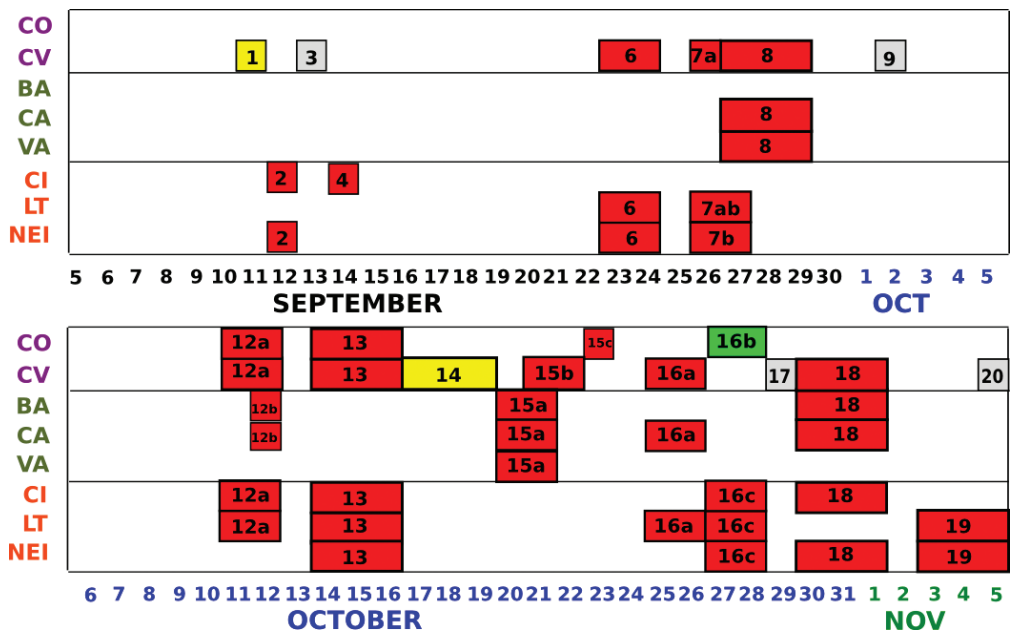

FIG. 7. Dates of the IOPs and sites affected by the studied events. IOPs dedicated primarily to heavy precipitation and flash-flood events are in red, to orographic precipitation in yellow, to strong wind events in green, and to lidar validation in gray. totals (not shown) were well above

the corresponding climatology for most regions in October and November, and were near average in September. Figure 7 and supplemental Table ES5 provide the specific dates of each IOP and their characteristics. IOPs dedicated to HPEs in October and the beginning of November were more numerous than in September 2012. From 5 to 22 September, an Atlantic ridge weather regime (Cassou et al. 2004) dominated, allowing for only a few HPEs over the eastern part of the basin (IOP2 and IOP4 affecting CI and NEI, respectively). Then, the weather regime shifted to a negative phase of the North Atlantic Oscillation (NAO'), providing for a favorable largescale environment for HPEs over all of the SOP domain from 23 to 30 September (IOP6, IOP7ab, IOP8). From 16 September to 3 October, Hurricane Nadine meandered around the Azores region, posing significant forecast challenges and reducing the 5-10-day predictability over the Atlantic and Mediterranean regions. After a break of about 10 days without HPE at the beginning of October corresponding to a positive phase of the NAO, weather patterns became favorable again to HPEs with blocking (16-26 October) and NAO- (27 October-5 November) patterns. Ten HPE-IOPs (IOP12ab, IOP13, IOP15abc, IOP16a, IOP16c, IOP18, and IOP19) were executed from 11 October through the end of SOP1.

Of the 16 HPE IOPs, nine were associated with flash flooding or local urban flooding. Tornadoes were also observed for three IOPs (IOP2, IOP8, IOP13a). Two IOPs were devoted only to orographic stratiform precipitation (IOP1 and IOP14) and one IOP to strong winds (IOP16b). Four IOPs (IOP3,
IOP9, IOP17, IOP20) were dedicated to lidar validation, while three (not listed) had to be canceled because of technical problems.

\section{SOME IOP HIGHLIGHTS. IOP8: Deep convection} associated with a mesoscale convergence line. The synoptic situation of IOP8 was characterized by an upperlevel cutoff low over southern Portugal at 0000 UTC 28 September, progressing eastward and reaching eastern Spain at 0000 UTC 29 September. Most of the heavy precipitation that affected the Murcia region was caused by a MCS over the region between 1000 and 1300 UTC 28 September. It displayed a V shape in the infrared satellite imagery (Fig. 8a). It formed along a convergence line between the warm and moist easterly low-level flow and the rapid westerly low-level flow between southern Spain and North Africa (Fig. 8b). The convergence zone, associated with a subsynoptic surface-pressure low, progressed northward reaching the north of Balearic Islands at 0000 UTC 29 September. Daily precipitation amounts reached $240 \mathrm{~mm}$ in Andalusia (27 September), $230 \mathrm{~mm}$ in Murcia (28 September), and $230 \mathrm{~mm}$ in Valencia (29 September). Thirteen people lost their lives in Andalusia and Murcia (southern Spain), and flooding resulted in 120 millions of euros of material losses. Even though the most significant impacts occurred outside the SOP domain, the ATR42 aircraft was able to survey the low-level flows feeding the deep convection while the F20 aircraft sampled the MCS that produced heavy precipitation over Murcia at the time it entered in the SOP domain. Seven dropsondes were launched during the flight. (Figure 13a shows 
the track of the F20 flight superimposed on the reflectivity composite at the time the aircraft was flying in the MCS.) The ATR42 flew in the same area from Montpellier to Menorca airport (track A-B in Fig. 9a), where it refueled, and then from Menorca to Montpellier (track B-C-A in Fig. 9a).

Because of midlevel clouds (well forecasted $24 \mathrm{~h}$ in advance), the flight level was limited to FL80 $(2.4 \mathrm{~km}$ MSL), just under the cloud base, with the LEANDRE 2 lidar pointing toward surface (Figs. 9b and 9c). These clouds became more and more unstable from north to south of the track. The LEANDRE 2 lidar sampled the northeasterly low-level flow along track A-B until about profile 350. The moist boundary layer was shallow, approximately 500-m depth. Above, a thin (a few hundred meters deep) dry and aerosolfree layer was trapped between the boundary layer and a moist layer $\left(7 \mathrm{~g} \mathrm{~kg}^{-1}\right)$ reaching $2 \mathrm{~km}$ ASL. This dry layer was replaced by a moist, aerosol-laden layer when approaching the Balearic Islands. The southern
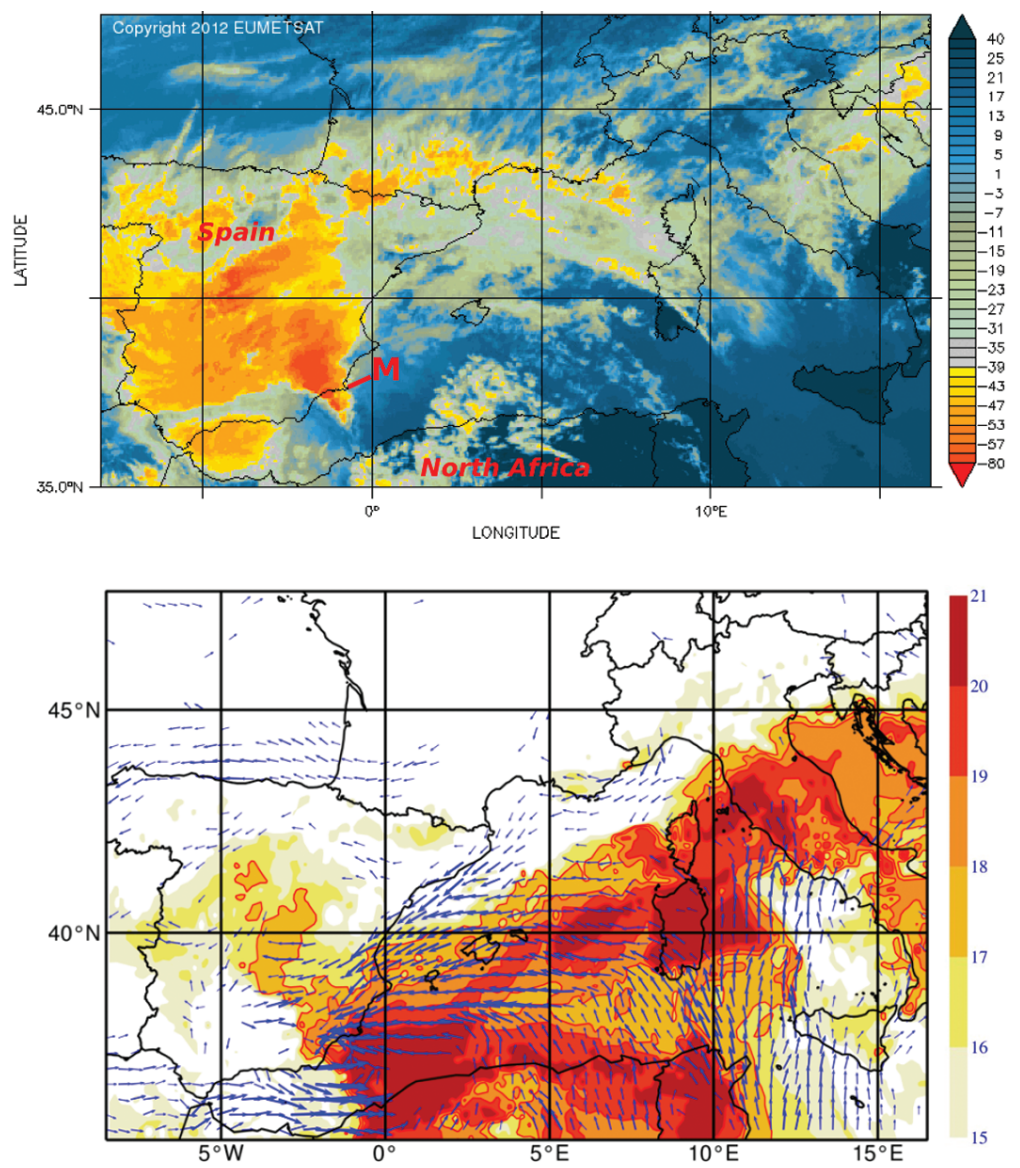

FIG. 8. (a) The 10.8- $\mu \mathrm{m}$ infrared brightness temperature from MSG at 1200 UTC 28 Sep 2012 showing the MCS (labeled M) that produced heavy precipitation over the Murcia region in Spain. (b) Wet bulb temperature $\left({ }^{\circ} \mathrm{C}\right.$ ) and wind (vectors) at $925 \mathrm{hPa}$ from AROMEWMED analysis at I200 UTC 28 September. part of the track (profiles 550-680) clearly sampled the easterly moist low-level flow just in front of the MCS. The boundary layer was deeper with water vapor mixing ratios around $12 \mathrm{~g} \mathrm{~kg}^{-1}$. To the north, along the return flight near Catalonia, the boundary layer air was dryer but moist and dusty between 1.5 and $2 \mathrm{~km}$. The ground-based Raman lidar in Menorca (WALI) and Candillargues (BASIL) confirmed the characteristics of the different flows captured by the airborne lidar (not shown). From 27 to 29 September, the frequency of the operational radiosoundings in the region (Murcia, Palma, Barcelona, Gibraltar, Madrid, and Cagliari in Sardinia) was increased to four per day. Instruments at the CO site, as well as two DO128 flights over Corsica on 28 September, monitored the upstream flow. All the collected observations will allow us to validate and improve the atmospheric models and their data assimilation system with a particular focus on the low-level flows over the western Mediterranean Sea that are not well captured by routine observations and on the evolution of the HPE on 29 September that was not well forecast. Models have also difficulties in simulating the dry layers revealed by the SOP1 observations of several IOPs. Their role on the microphysics and dynamics of the precipitating systems should be further investigated and related to rainfall forecast errors.

IOPI6a: Quasi-stationary or slow propagating MCSs. IOP16a was a case of deep convection that developed over the western Mediterranean Sea and affected the coastal regions. The synoptic situation was characterized by a deep upper-level low centered over the Iberian Peninsula moving slowly eastward. Ahead of the main frontal system, several MCSs developed within the warm and moist low-level south/southwesterly flow. A first one (labeled MCS1 in Fig. 14) formed along the Catalonia coast during the evening of 25 October. While progressing slowly northeastward during the night and early morning, it split into two MCSs (see Fig. 10). A third smaller and quasi-stationary convective system (labeled MCS2 in Fig. 10) affected the Liguria coast 
most of the day. The deep convection offshore Sardinia and Corsica, labeled DC in Fig. 10, was renewed all day over the sea while extending eastward to reach central Italy during the evening on 26 October. Daily precipitation on 26 October reached $250 \mathrm{~mm}$ and $170 \mathrm{~mm}$ over LT and $\mathrm{CV}$, respectively.

Almost all the on-demand SOP1 instruments were deployed for this event (see Table ES5 in the supplement). The ATR42 flew during the night from 25 to 26 October to survey the moist and warm air upstream of MCS1. Then, the F20 flew within MCS1a from 0630 to 0955 UTC and in MCS1b from 1245 to 1500 UTC. Figures $11 \mathrm{a}$ and $11 \mathrm{~b}$ show the reflectivity and Doppler radial velocity measured by the RASTA cloud radar during the afternoon flight that was guided by the science team at HOC using radar, satellite, and lightning observations superimposed to the real-time position of the aircraft. The aircraft first sampled the stratiform part (A-B track section; Fig. 11d) of the MCS, with the melting layer around $3 \mathrm{~km}$ detected in both reflectivity and velocity fields. Then the aircraft sampled the leading edge of the MCS (B-C track section; Fig. 11d) at 4.5 and $7 \mathrm{~km}$ where new convective cells developed. Series of updrafts and downdrafts were observed within that region (Fig. 11b). After ice crystal nucleation and primary growth by water vapor diffusion, subsequent crystal growth in vigorous mesoscale convective cloud systems can be significantly dominated by riming and aggregation processes. For IOP16a, Fig. 11c shows examples of hydrometeor images sampled during the flight for the stratiform (A-B and C-D sections) and convective (B-C section) parts. The stratiform parts show considerable amounts of aggregation, including clear secondary growth by vapor diffusion. Riming can be observed in the convective part (B-C section), but it is far less pronounced as compared to vigorous tropical convection, particularly over the continent (Lawson et al. 2010), where indicators of pristine ice are rarely observed, and growth processes of riming and aggregation largely dominate over growth by vapor diffusion. One interesting feature in the IOP16a case is the presence of oriented aggregates of columns in the convective part (second row for B-C section in Fig. 11c), possibly due to a stronger electrical field. In general, images show numerous transitions of the dominant growth regime between riming and aggregation at small scale (a few hundreds of meters).

From 25 to 26 October, the P/T Provence performed air-sea flux and swell measurements, launched radiosoundings, and obtained CTD profiles every $3 \mathrm{~h}$ 


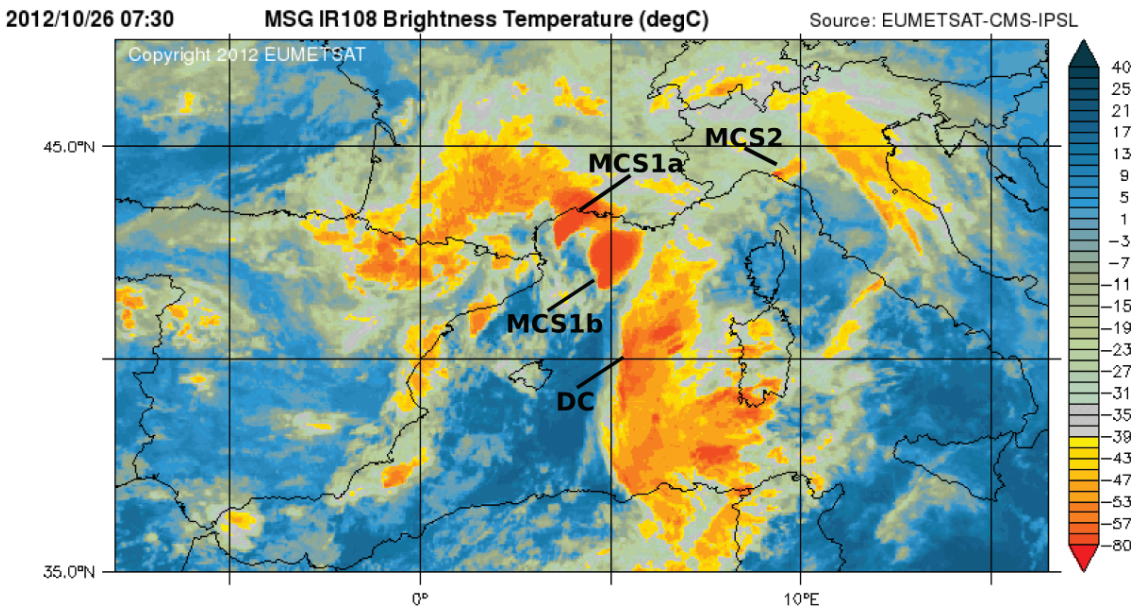

Fig. 10. The 10.8- $\mu \mathrm{m}$ infrared brightness temperature from MSG at 0730 UTC 26 Oct 2012.

a)

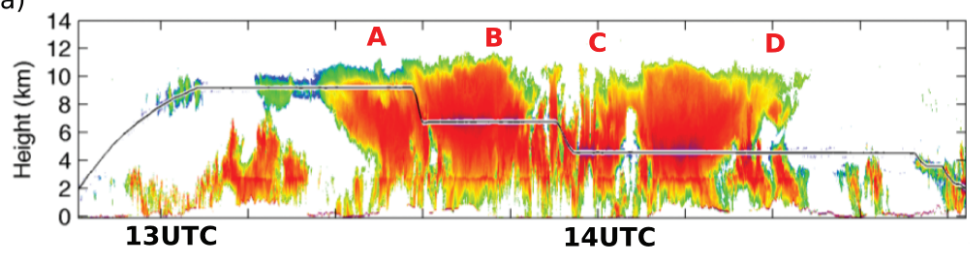

$\mathrm{Z}(\mathrm{dBZ})$

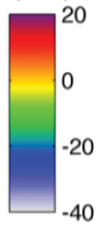

b)

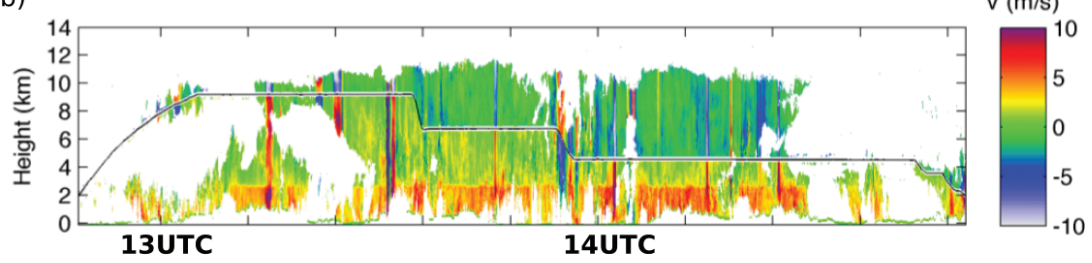

C)

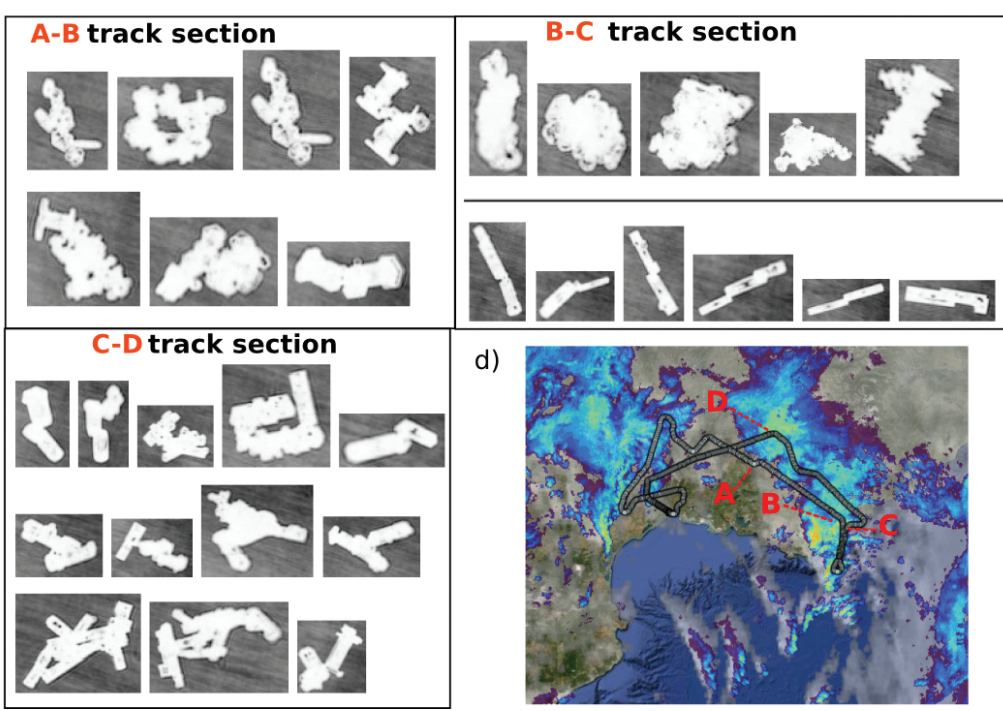

FIG. II. (a) Reflectivity from the RASTA cloud radar along the flight track shown in (d), with the aircraft flight altitude indicated by the gray line. (b) As in (a), but for vertical Doppler velocity from the RASTA cloud radar. (c) Images of hydrometeors sampled during the three flight track sections A-B, B-C, and C-D as defined in (d). (d) F20 track flight from I245 to I500 UTC superimposed on the reflectivity composite at 1400 UTC 26 October. at a fixed position (Fig. 12c). The ocean profiles of salinity, density, and potential temperature (Fig. 12b) are compared to the ones collected during IOP7a one month prior (Fig. 12a). The surface layer has cooled down (from about $21^{\circ} \mathrm{C}$ during IOP7a to about $19.5^{\circ} \mathrm{C}$ for IOP $16 \mathrm{a}$ ), and the mixed layer was $\sim 15 \mathrm{~m}$ deeper (from about $30 \mathrm{~m}$ for IOP7a to about $45 \mathrm{~m}$ for IOP16a). The glider named CAMPE that performed the transect shown in Fig. 16c confirmed this mixed-layer depth (temperature above $\sim 14^{\circ} \mathrm{C}$ ), with a deeper mixed layer between Sardinia and Balearic Islands (Fig. 12d).

The heavy rainfall induced flash flooding in Liguria and urban flash flooding in the Toulon city of the French Riviera, causing two fatalities. However, the hydrological response in the Ardèche and Gard instrumented catchments were not noteworthy, despite the $100-150 \mathrm{~mm}$ of daily rainfall. In fact, the soil progressively moistened throughout SOP1, reaching near-saturated conditions only at the beginning of November. Figure 13 shows an example of geochemical measurements taken over the Valescure watershed during the event. The electrical conductivity slightly decreased when river flow increased, meaning that only a small percentage of surface runoff contributed to the river flow during peak flow (Fig. 13a). This is confirmed in Fig. 13b by the significant increase of terrigenous elements $(\mathrm{Al}, \mathrm{La})$ indicating a significant contribution from shallow, subsurface flow. 
IOP16a represents a "golden case" enabling us to address the science issues identified in section 2 , including convection initiation and stationarity, cloud-precipitation processes, air-sea coupled processes prior to and during the HPE, and hydrological functioning and sensitivity to initial conditions in the Gard and Ardèche watersheds.

1OP6: A long-lasting propagating convective line. The synoptic situation was characterized by a cold upperlevel trough moving over France and northern Italy. The warm sector south of the cold front became very active over the Massif Central in the early morning hours on 24 September,

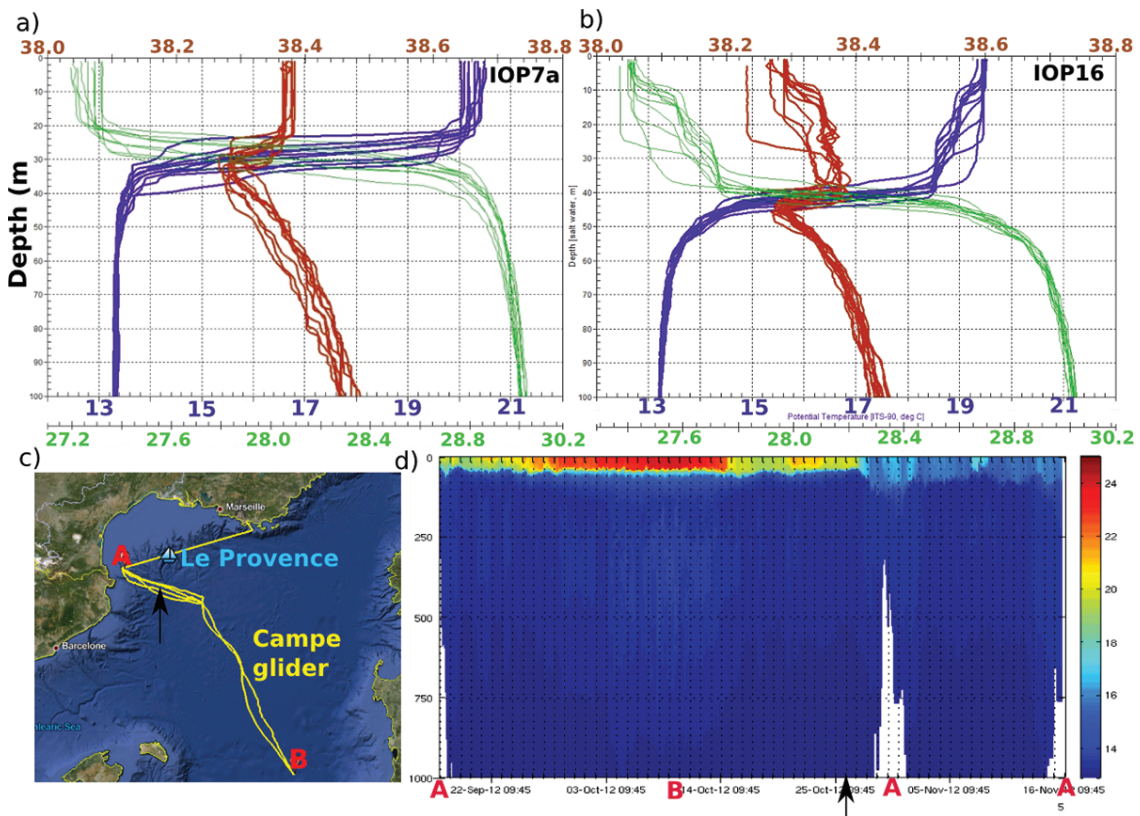

Fig. 12. (a) Potential temperature (blue; ${ }^{\circ} \mathrm{C}$ ), salinity (brown; psu), and density (green; $\mathrm{kg} \mathrm{m}^{-3}$ ) of the $0-100-\mathrm{m}$ ocean CTD profiles performed by the PIT Provence during IOP7a. (b) As in (a), but for IOPI6a. (c) The CAMPE glider transect from 22 September to 16 November and position of the P/T Provence during IOPI6a. (d) The $0-100-\mathrm{m}$ potential temperature profiles along the CAMPE glider transect. The black arrow indicates the position of the CAMPE glider during IOPI6a. fed by a marine southerly low-level flow. A bow echo formed and produced wind gusts up to $100 \mathrm{~km} \mathrm{~h}^{-1}$ and hourly rainfall rates from 50 to $60 \mathrm{~mm}$ recorded over $\mathrm{CV}$. Then, the system evolved into a squall line extending from the Ligurian Sea to the Po Valley and propagated eastward toward NEI. The surface rainfall totals reached $160 \mathrm{~mm}$ in $12 \mathrm{~h}$ in NEI with wind gusts uprooting trees. The bow echo was captured well by ground instruments in CV including two operational Météo-France $S$-band radars and three research radars (MXPOL X-band polarimetric Doppler radar and two X-band radars) that will allow unprecedented intercomparison of $\mathrm{X}$ - and S-band radars and detailed analysis of the phenomena (Fig. 14). The reflectivity and velocity at $1000 \mathrm{~m}$ (Fig. 14b) retrieved from the Météo-France radars (Bousquet et al. 2008) show the convergence line between the low-level marine southerly flow and the southwesterly flow associated with the frontal system. Reflectivity up to $60 \mathrm{dBZ}$ was recorded within the bow echo by the operational Météo-France radars and the MXPOL. They also recorded radial
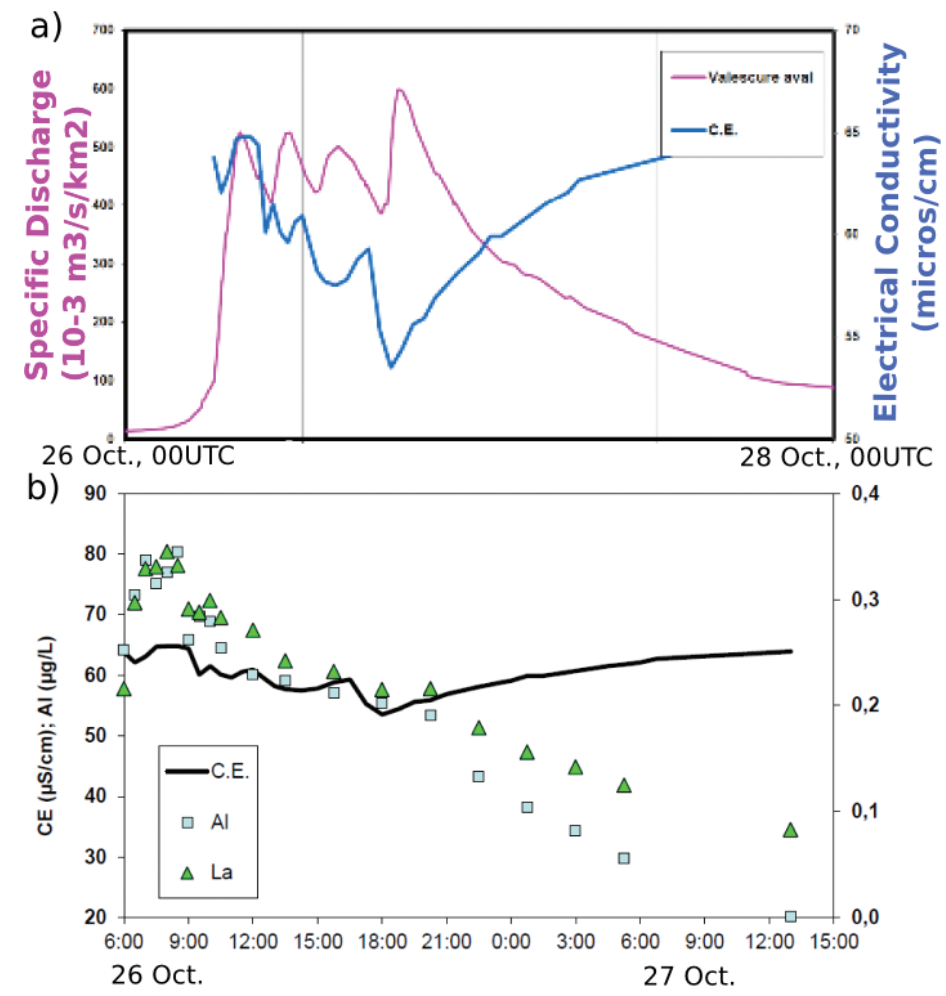

FIG. 13. (a) Specific discharge (pink curve; $10^{-3} \mathrm{~m}^{3} \mathrm{~s}^{-1} \mathrm{~km}^{-2}$ ) and electrical conductivity ( $\left.\mu \mathrm{s} \mathrm{cm}^{-1}\right)$. (b) Electrical conductivity and $\mathrm{Al}$ and La terrigenous elements for the Valescure watershed from 26 to 27 October (source: Geochemistry group and Lama, HSM). 
Doppler velocities up to $40 \mathrm{~m} \mathrm{~s}^{-1}$ associated with the bow echo (not shown). The hydrometeor classification (Al-Sakka et al. 2013) identified hail within the convective line and, sequentially, dry snow, wet snow, and ice as the radar range and thus height increased (Fig. 14c). The whole suite of observations from research radars, disdrometers, and Microrain radars over the CV site as well the microphysical probes and cloud radar onboard the F20 offer us a unique opportunity to validate hydrometeor classification results in the future. The signature of the convective line system is also clear in the Lightning Mapping Array 10-min records (Fig. 15). The most active electrical cell with lightning flashes reaching up to $13 \mathrm{~km}$ is located at the southern tip of the bow echo whereas the lightning activity within the bow echo is multicellular with a maximum of activity around $8 \mathrm{~km}$. These different characteristics should be related to the microphysical properties of the convective line that will be retrieved from the aforementioned instruments. IOP6 represents an example of a very well-characterized case by both the ground instruments deployed over one of the HyMeX sites and the airborne instruments. It will allow us to further study the relationships between storm dynamics, microphysical processes, and lightning, to validate and improve radar products (quantitative precipitation estimation, refractivity, hydrometeor, and wind retrievals), and to develop and improve microphysical parameterizations, convection schemes, and electricity modeling.

SUMMARY AND OUTLOOKS. The observations collected by more than 200 research instruments deployed during HyMeX SOP1 constitute an unprecedented dataset. Unique relative to previous field experiments in the region, the atmosphere, ocean, and land surfaces were all sampled in order to study the interaction and feedbacks between the different components of the hydrologic cycle during heavy precipitation and flash floods. For the latter, a)

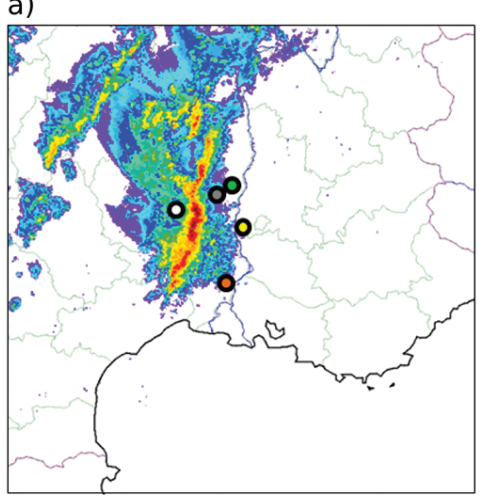

d) $\operatorname{Mon} \operatorname{Sep} 24$ 02:05:14 2012 $\mathrm{z}_{\mathrm{h}}[\mathrm{dBZZ}], \mathrm{oz}=216.3$ de
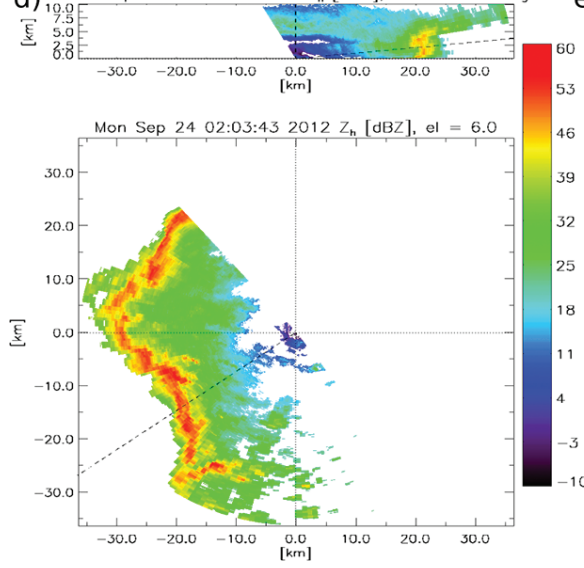

b)

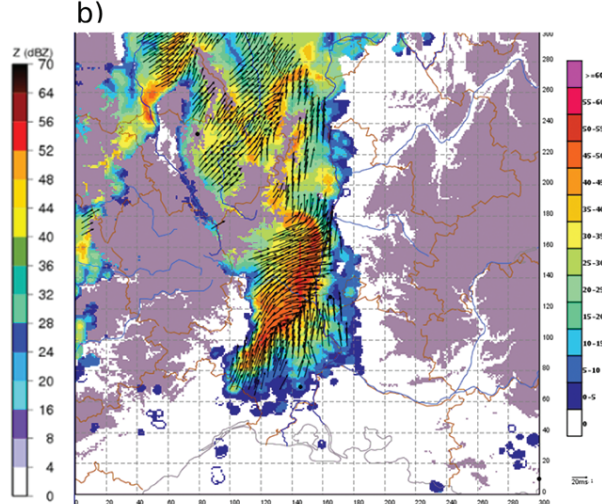

e)

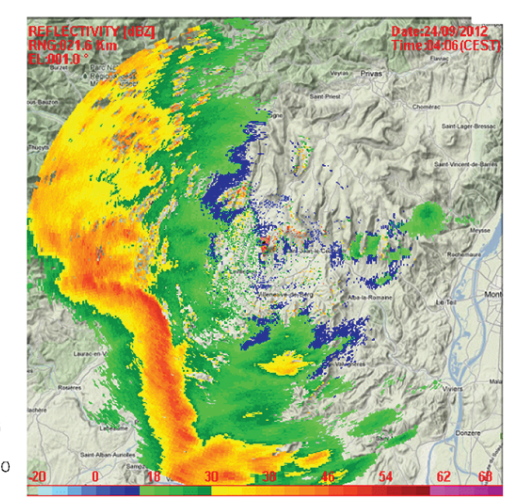

c)

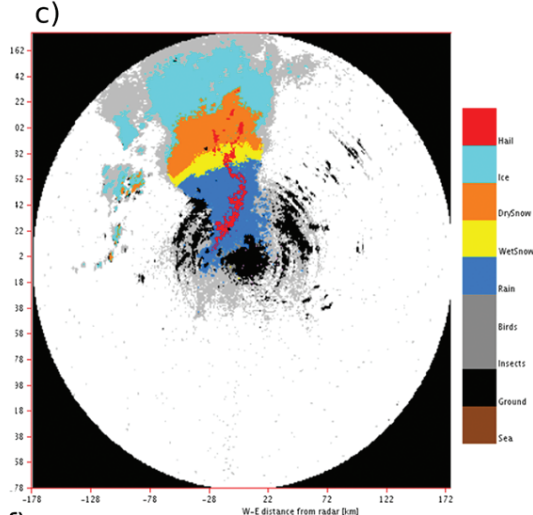

f)

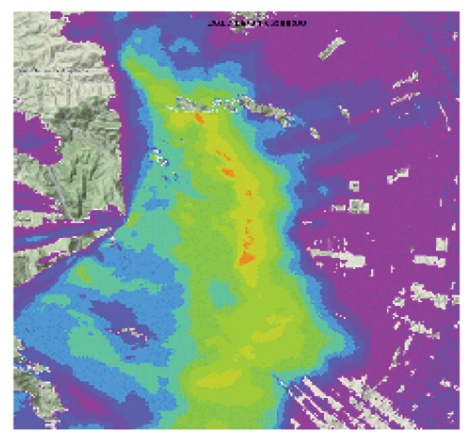

FIG. 14. (a) Météo-France reflectivity composite at 0230 UTC and location of the Météo-France operational S-band polarimetric Doppler radar at Nîmes (orange bullet) and S-band Doppler radar at Bollène (yellow bullet), of the MXPOL radar from EPFL at Montbrun (green bullet), and of the two X-band radars from LaMP in Le Chade (gray bullet) and La Bombine (white bullet). (b) Wind retrieval and reflectivity at $1000 \mathrm{~m}$ from the Météo-France radars at 0230 UTC. (c) Hydrometeor classification from the Nîmes radar $\left(0.4^{\circ}\right.$ elevation PPI) at 0230 UTC. (d) PPI and RHI of radar reflectivity (corrected for attenuation) from MXPOL radar at $0200 \mathrm{UTC}$. (e) Reflectivity from X-band radar at Le Chade. (f) Reflectivity from X-band radar at La Bombine. 
measurements over the instrumented watersheds will continue during the HyMeX enhanced observation period (EOP) through the end of 2014 to capture additional flood events.

During the coming months, the data will be made available in the HyMeX database for noncommercial research and educational activities related to the program. Several datasets are already available, including the observations from operational networks. A great success of HyMeX is the collection of the rain gauge networks over France, Italy, and Spain, with an exceptional and unprecedented high-density and good coverage as illustrated by Fig. 6. A high-resolution reanalysis of SOP1 using the AROME-WMED NWP system is currently underway. Further forecast improvements can be expected by including HyMeX experimental observations, such as those obtained over the sea where routine observations are fewer than over land and within cloudy and precipitating areas, within the data assimilation

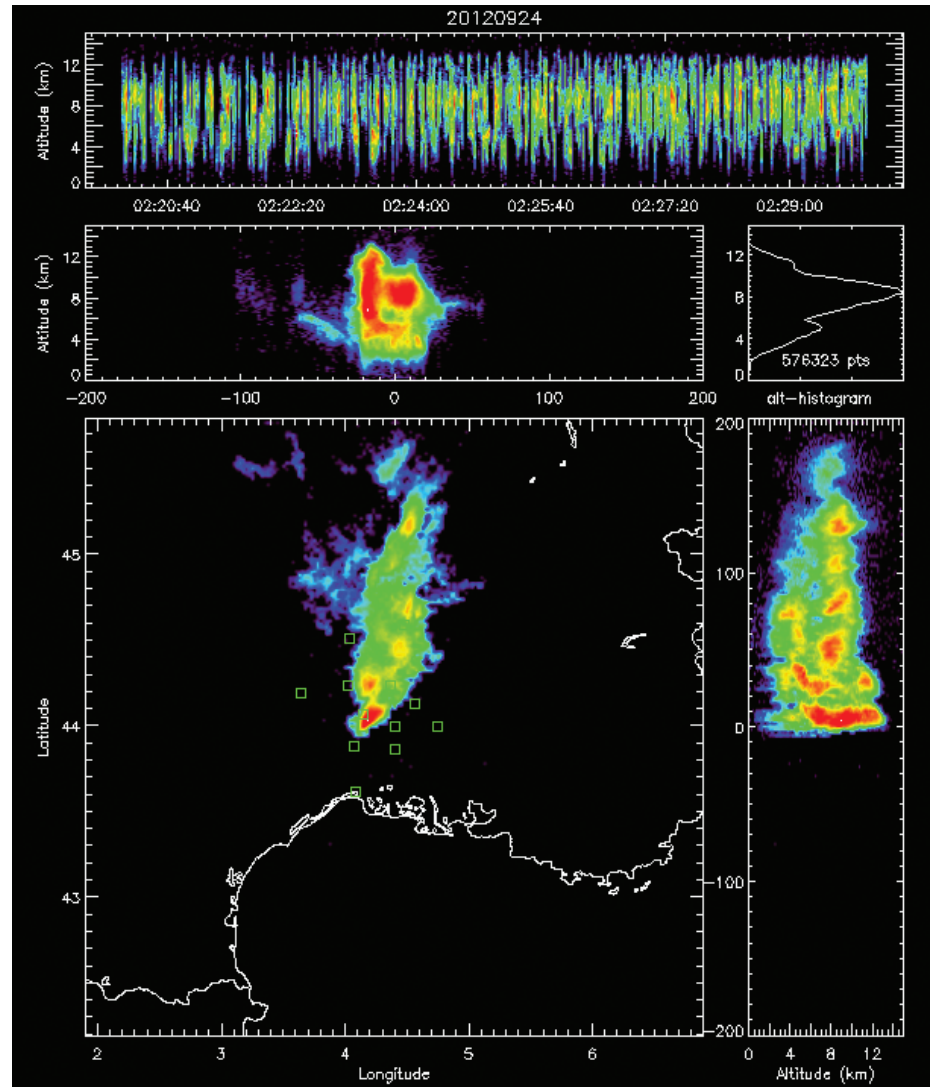

FIG. I5. I0-min VHF source density between 0220 and 0230 UTC 24 September from the Lightning Mapping Array. The source density is plotted in decimal logarithm (blue is the lowest source density, red the highest). Squares indicate the location of the 12 LMA stations. Shown are (top) height-time series, (middle) height-longitude series, and (bottom) heightlatitude series. systems. Assimilation of new observation types (e.g., lidar water vapor, radar refractivity or polarimetric observations, lightning) will be developed and evaluated.

SOP1 provides a wealth of observations that will be used during the remaining HyMeX decade to further progress our understanding of the complex interactions that govern the location and severity of heavy precipitation and associated flash floods. Moreover, the SOP1 datasets will accommodate an extensive intercomparison and validation of NWP models, will be used to improve the atmosphere-ocean hydrological models, and will advance the predictability and representation of high-impact events in regional climate simulations.

ACKNOWLEDGMENTS. Although the authorship of this overview paper is significant, more scientists contributed to it and many more were involved in the field campaign: all deserve our grateful thanks. A special mention is due for the ten Météo-France forecasters-C. Calas, E. Chabot, J. Crémoux, A.-C. Fontan, L. Goulet, M. Kreitz, J.-M. Poulet, B. Roulet, F. Saix, and F. Vaysseand for the forecasters of the secondary operations centers, without whose forecasting support the success of the field campaign would have not been possible. HyMeX SOP1 was supported by CNRS, Météo-France, CNES, IRSTEA, and INRA through the large interdisciplinary international program MISTRALS (Mediterranean Integrated Studies at Regional and Local Scales) dedicated to the understanding of the Mediterranean Basin environmental process (www.mistralshome.org), as well as by, in France, IRD, IFSTTAR, IFREMER, IGN, CEA, ONERA, Mercator-Océan, Météorage, the Universities of Aix-Marseille, Avignon, ClermontFerrand, Corse, Grenoble, Littoral Côte d'Opale, Montpellier, Nice Sophia-Antipolis, Perpignan, Pierre et Marie Curie, Polynésie Française, Sud Toulon-Var, Toulouse, and Versailles-Saint Quentin, Mines d'Ales School, Grenoble Institut of Technology, ENSTA, and Collectivité Territoriale de Corse; in Germany, the Karlsruhe Institute of Technology (KIT), DLR, GFZ Potsdam, and TU Braunschweig; in Italy, CNR, the Universities of L'Aquila, Padova, and RomaSapienza, many regional services (ARPA SIMC, ARPA Piemonte, ARPAV, ARPA Friuli Venezia Giulia, and OSMER, among others), 
ISPRA, the Italian Civil Protection Department, CIMA, ENEA, and LaMMA; in Spain, AEMET, IMEDEA, EUSKALMET, the Universities of Barcelona and the Balearic Islands, and SMC; in the United States, NASA, New Mexico Tech (NMT), NOAA, and the University of Connecticut; in Switzerland, EPFL and ETH; in the Netherlands, the Universities of Delft and Wageningen; in Austria, OVE and Vienna University; in Greece, NOA; in Croatia, DHZ; and by the following European agencies: EUMETNET, EUCLID, and EUMETSAT.

The field campaign was sponsored by Grants MISTRALS/HyMeX, A NR-2011-BS56-027 FLOODSCALE, ANR-11-BS56-0005 IODA-MED, CSTB-BAMED, CPER-FEDER CORSiCA, EUCOSDTS-HyMeX, EU-FP7 EUROFLEETS, EU-FP7 PERSEUS, and EU-FP7 DRIHM.

\section{REFERENCES}

Al-Sakka, H., A.-A. Boumahmoud, B. Fradon, S. J. Frasier, and P. Tabary, 2013: A new fuzzy logic hydrometeor classification scheme applied to the French X-, C-, and S-band polarimetric radars. J. Appl. Meteor. Climatol., 52, 2328-2344.

Bluestein, H. B., and M. H. Jain, 1985: Formation of mesoscale lines of precipitation: Severe squall lines in Oklahoma during the spring. J. Atmos. Sci., 42, 1711-1732.

Bonnifait, L., G. Delrieu, M. Le Lay, B. Boudevillain, A. Masson, P. Belleudy, E. Gaume, and G.-M. Saulnier, 2009: Distributed hydrologic and hydraulic modelling with radar rainfall input: Reconstruction of the 8-9 September 2002 catastrophic flood event in the Gard region, France. Adv. Water Resour., 32, 1077-1089.

Borga, M., E. Gaume, J. D. Creutin, and L. Marchi, 2008: Surveying flash floods: Gauging the ungauged extremes. Hydrol. Processes, 22, 3883-3885.

Bougeault, P., and Coauthors, 2001: The MAP special observing period. Bull. Amer. Meteor. Soc., 82, 433-462.

Bouilloud, L., G. Delrieu, B. Boudevillain, and P. E. Kirstetter, 2010: Radar rainfall estimation in the context of post-event analysis of flash-flood events. J. Hydrol., 394, 17-27.

Bousquet, O., and B. F. Smull, 2006: Observed mass transports accompanying upstream orographic blocking during MAP IOP8. Quart. J. Roy. Meteor. Soc., 132, 2393-2413.

_-, P. Tabary, and J. P. du Châtelet, 2008: Operational multiple-Doppler wind retrieval inferred from longrange radial velocity measurements. J. Appl. Meteor. Climatol., 47, 2929-2945.
Braud, I., H. Roux, S. Anquetin, M.-M. Maubourguet, C. Manus, P. Viallet, and D. Dartus, 2010: The use of distributed hydrological models for the Gard 2002 flash flood event: Analysis of associated hydrological processes. J. Hydrol., 394, 162-181.

Bresson, E., V. Ducrocq, O. Nuissier, D. Ricard, and C. de Saint-Aubin, 2012: Idealized numerical simulations of quasi-stationary convective systems over the northwestern Mediterranean complex terrain. Quart. J. Roy. Meteor. Soc., 138, 1751-1763.

Buzzi, A., and L. Foschini, 2000: Mesoscale meteorological features associated with heavy precipitation in the southern Alpine region. Meteor. Atmos. Phys., 72, 131-146.

Campins, J., A. Jansa, and A. Genovés, 2006: Threedimensional structure of western Mediterranean cyclones. Int. J. Climatol., 26, 323-343.

Cassou, C., L. Terray, J. W. Hurrell, and C. Deser, 2004: North Atlantic winter climate regimes: Spatial asymmetry, stationarity with time, and oceanic forcing. J. Climate, 17, 1055-1068.

Corsmeier, U., R. Hankers, and A. Wieser, 2001: Airborne turbulence measurements in the lower troposphere onboard the research aircraft Dornier 128-6, D-IBUF. Meteor. Z., 10, 315-329.

Davolio, S., D. Mastrangelo, M. M. Miglietta, O. Drofa, A. Buzzi, and P. Malguzzi, 2009: High resolution simulations of a flash flood near Venice. Nat. Hazards Earth Syst. Sci., 9, 1671-1678.

Delrieu, G., and Coauthors, 2005: The catastrophic flash-flood event of 8-9 September 2002 in the Gard region, France: A first case study for the CevennesVivarais Mediterranean Hydrometeorological Observatory. J. Hydrometeor., 6, 34-52.

Drobinski, P., and Coauthors, 2014: HyMeX, a 10-year multidisciplinary program on the Mediterranean water cycle. Bull. Amer. Meteor. Soc., 95, 1063-1082.

Ducrocq, V., O. Nuissier, D. Ricard, C. Lebeaupin, and T. Thouvenin, 2008: A numerical study of three catastrophic precipitating events over southern France. II: Mesoscale triggering and stationarity factors. Quart. J. Roy. Meteor. Soc., 134, 131-145.

Duffourg, F., and V. Ducrocq, 2011: Origin of the moisture feeding the heavy precipitating systems over southeastern France. Nat. Hazards Earth Syst. Sci., 11, 1163-1178.

— Mediterranean heavy precipitation: A method based on finely designed water budgets. Atmos. Sci. Lett., 14, 133-138.

Ferretti, R., S. Low-Nam, and R. Rotunno, 2000: Numerical simulations of the Piedmont flood of 4-6 November 1994. Tellus, 52A, 162-180. 
Gaume, E., and Coauthors, 2009: A compilation of data on European flash floods. J. Hydrol., 367, 70-78.

Jansa, A., A. Genoves, M. A. Picornell, J. Campins, R. Riosalido, and O. Carretero, 2001: Western Mediterranean cyclones and heavy rain. Part 2: Statistical approach. Meteor. Appl., 8, 43-56.

—, P. Arbogast, A. Doerenbecher, L. Garcies, A. Genoves, V. Homar, S. Klink, D. Richardson, and C. Sahin, 2011: A new approach to sensitivity climatologies: The DTS-MEDEX-2009 campaign. Nat. Hazards Earth Syst. Sci., 11, 2381-2390.

Kalthoff, N., and Coauthors, 2013: Dry and moist convection in the boundary layer over the Black ForestA combined analysis of in situ and remote sensing data. Meteor. Z., 22, 445-461, doi:10.1127/0941 $-2948 / 2013 / 0417$.

Lambert, D., M. Mallet, V. Ducrocq, F. Dulac, F. Gheusi, and N. Kalthoff, 2011: CORSiCA: A Mediterranean atmospheric and oceanographic observatory in Corsica within the framework of HyMeX and ChArMEx. Adv. Geosci., 26, 125-131.

Lascaux, F., E. Richard, C. Keil, and O. Bock, 2004: Impact of the MAP reanalysis on the numerical simulation of the MAP-IOP2a convective system. Meteor. Z., 13, 49-54.

Lawson, R. P., E. Jensen, D. L. Mitchell, B. Baker, Q. Mo, and B. Pilson, 2010: Microphysical and radiative properties of tropical clouds investigated in TC4 and NAMMA. J. Geophys. Res., 115, D00J08, doi:10.1029/2009JD013017.

Lebeaupin, C., V. Ducrocq, and H. Giordani, 2006: Sensitivity of torrential rain events to the sea surface temperature based on high-resolution numerical forecasts. J. Geophys. Res., 111, D12110, doi:10.1029/2005JD006541.

Lebeaupin Brossier, C., P. Drobinski, K. Béranger, S. Bastin, and F. Orain, 2013: Ocean memory effect on the dynamics of coastal heavy precipitation preceded by a mistral event in the northwestern Mediterranean. Quart. J. Roy. Meteor. Soc., 139, 1583-1597.

Legain, D., O. Bousquet, T. Douffet, D. Tzanos, E. Moulin, J. Barrie, and J.-B. Renard, 2013: Highfrequency boundary layer profiling with reusable radiosondes. Atmos. Meas. Tech., 6, 2195-2205.

Le Lay, M., and G.M. Saulnier, 2007: Exploring the signature of climate and landscape spatial variabilities in flash flood events: Case of the 8-9 September 2002 Cévennes-Vivarais catastrophic event. Geophys. Res. Lett., 34, L13401, doi:10.1029/2007GL029746.

Llasat, C., M. Llasat-Botija, O. Petrucci, A. A. Pasqua, J. Rosselló, F. Vinet, and L. Boissier, 2013: Towards a database on societal impact of Mediterranean floods within the framework of the HYMEX project. Nat. Hazards Earth Syst. Sci., 13, 1337-1350.

Mariotti, A., M. V. Struglia, N. Zeng, and K.-M. Lau, 2002: The hydrological cycle in the Mediterranean region and implications for the water budget of the Mediterranean Sea. J. Climate, 15, 1674-1690.

Miglietta, M. M., and R. Rotunno, 2009: Numerical simulations of conditionally unstable flows over a mountain ridge. J. Atmos. Sci., 66, 1865-1885.

$\longrightarrow$, and — 2010: Numerical simulations of lowCAPE flows over a mountain ridge. J. Atmos. Sci., 67, 2391-2401.

Munich RE, 2011: Natural catastrophes 2010: Analyses, assessments, positions. Topics GEO No. 302-06735, $52 \mathrm{pp}$.

_ , 2012: Natural catastrophes 2011, Analyses, assessments, positions. Topics GEO No. 302-07225, 58 pp.

Norbiato, D., M. Borga, R. Merz, G. Blöschl, and A. Carton, 2009: Controls on event runoff coefficients in the eastern Italian Alps. J. Hydrol., 375, 312-325.

Nuissier, O., V. Ducrocq, D. Ricard, C. Lebeaupin, and S. Anquetin, 2008: A numerical study of three catastrophic precipitating events over southern France. I: Numerical framework and synoptic ingredients. Quart. J. Roy. Meteor. Soc., 134, 111-130.

— , B. Joly, A. Joly, V. Ducrocq, and P. Arbogast, 2011: A statistical downscaling to identify the large-scale circulation patterns associated with heavy precipitation events over southern France. Quart. J. Roy. Meteor. Soc., 137, 1812-1827.

Prates, C., D. Richardson, and C. Sahin, 2009: Final report of the PREVIEW observation Data Targeting System (DTS). ECMWF Tech. Memo. 581, 31 pp.

Protat, A., and Coauthors, 2009: Assessment of Cloudsat reflectivity measurements and ice cloud properties using ground-based and airborne cloud radar observations. J. Atmos. Oceanic Technol., 26, 1717-1741.

Rebora, N., and Coauthors, 2013: Extreme rainfall in the Mediterranean: What can we learn from observations? J. Hydrometeor., 14, 906-922.

Romero, R., C. A. Doswell, and C. Ramis, 2000: Mesoscale numerical study of two cases of long-lived quasi-stationary convective systems over eastern Spain. Mon. Wea. Rev., 128, 3731-3751.

Rotunno, R., and R. Ferretti, 2001: Orographic effects on rainfall in MAP cases IOP 2b and IOP 8. Quart. J. Roy. Meteor. Soc., 129, 373-390.

—, and R. A. Houze, 2007: Lessons on orographic precipitation from the Mesoscale Alpine Program. Quart. J. Roy. Meteor. Soc., 133, 811-830.

Ruin, I., J. D. Creutin, S. Anquetin, and C. Lutoff, 2008: Human exposure to flash floods-Relation between 
flood parameters and human vulnerability during a storm of September 2002 in southern France. J. Hydrol., 361, 199-213.

Seity, Y., P. Brousseau, S. Malardel, G. Hello, P. Bénard, F. Bouttier, C. Lac, and V. Masson, 2011: The AROME-France convective-scale operational model. Mon. Wea. Rev., 139, 976-991.

Sénési, S., P. Bougeault, J.-L. Cheze, P. Cosentino, and R.-M. Thepenier, 1996: The Vaison-La-Romaine flash flood: Mesoscale analysis and predictability issues. Wea. Forecasting, 11, 417-442.

Silvestro, F., S. Gabellani, F. Giannoni, A. Parodi, N. Rebora, R. Rudari, and F. Siccardi, 2012: A hydrological analysis of the 4 November 2011 event in Genoa, 2012. Nat. Hazards Earth Syst. Sci., 12, 2743-2752.
Testor, P., and Coauthors, 2010: Gliders as a component of future observing systems. Proceedings of the “OceanObs'09: Sustained Ocean Observations and Information for Society" Conference, Vol. 2, ESA Publication WPP-306, doi:10.5270/OceanObs09.cwp.89.

Tramblay, Y., C. Bouvier, C. Martin, J.-F. Didon-Lescot, D. Todorovik, and J.-M. Domergue, 2010: Assessment of initial soil moisture conditions for event-based rainfall-runoff modelling. J. Hydrol., 387, 176-187.

Turato, B., O. Reale, and F. Siccardi, 2004: Water vapor sources of the October 2000 Piedmont flood. J. Hydrometeor., 5, 693-712.

Winschall, A., S. Pfahl, H. Sodemann, and H. Wernli, 2012: Impact of North Atlantic evaporation hot spots on southern Alpine heavy precipitation events. Quart. J. Roy. Meteor. Soc., 138, 1245-1258.

\section{NEW FROM AMS BOOKS!}

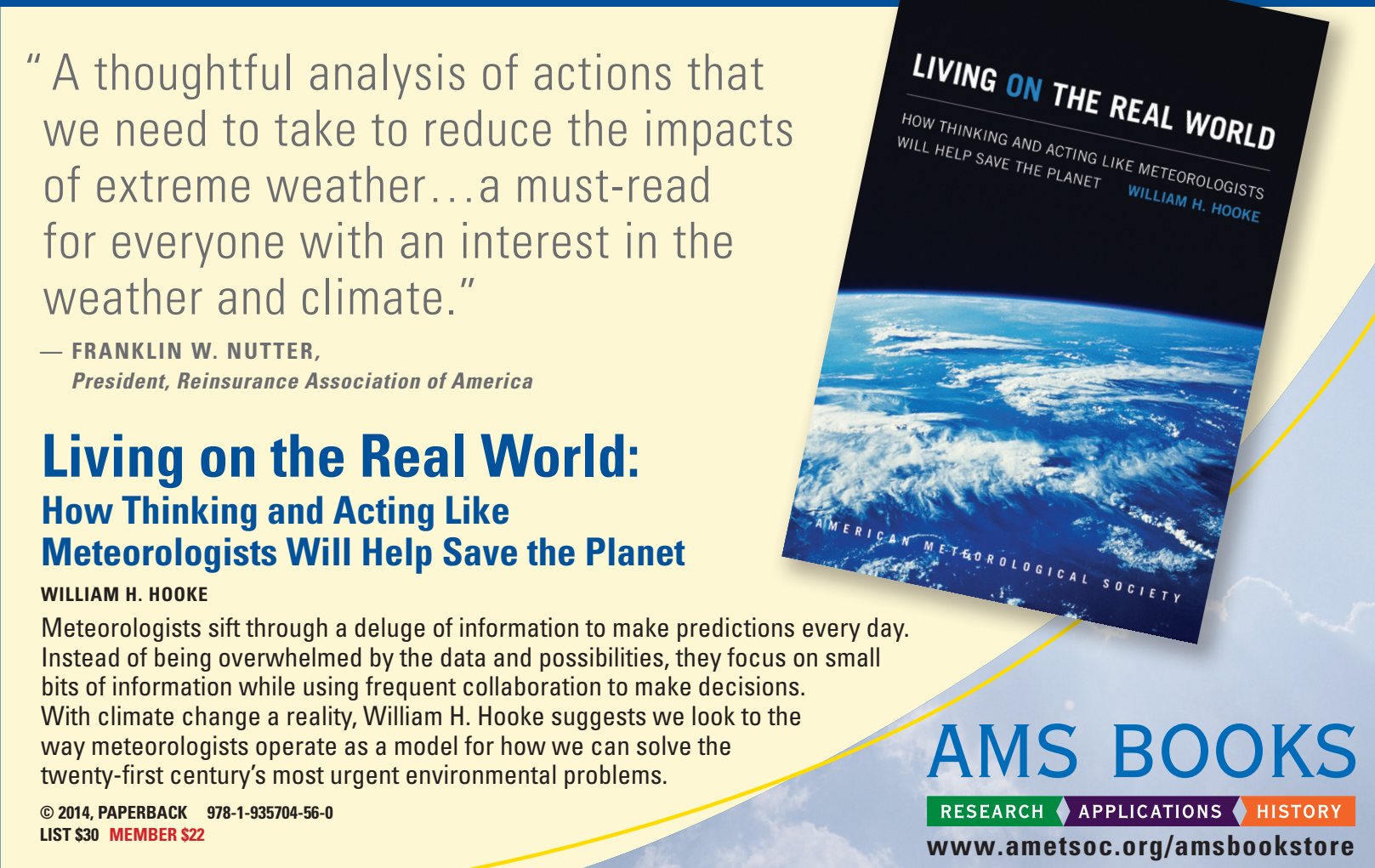

